\title{
Aansluiting opleiding-werk en arbeidsmarktpositie van civiel-ingenieurs
}

Citation for published version (APA):

Ramaekers, G. W. M., \& Dekker, R. (1993). Aansluiting opleiding-werk en arbeidsmarktpositie van civielingenieurs. Researchcentrum voor Onderwijs en Arbeidsmarkt, Faculteit der Economische Wetenschappen. ROA Reports No. 3 https://doi.org/10.26481/umarep.1993003

Document status and date:

Published: 01/01/1993

DOI:

10.26481/umarep.1993003

Document Version:

Publisher's PDF, also known as Version of record

\section{Please check the document version of this publication:}

- A submitted manuscript is the version of the article upon submission and before peer-review. There can be important differences between the submitted version and the official published version of record.

People interested in the research are advised to contact the author for the final version of the publication, or visit the DOI to the publisher's website.

- The final author version and the galley proof are versions of the publication after peer review.

- The final published version features the final layout of the paper including the volume, issue and page numbers.

Link to publication

\footnotetext{
General rights rights.

- You may freely distribute the URL identifying the publication in the public portal. please follow below link for the End User Agreement:

www.umlib.nl/taverne-license

Take down policy

If you believe that this document breaches copyright please contact us at:

repository@maastrichtuniversity.nl

providing details and we will investigate your claim.
}

Copyright and moral rights for the publications made accessible in the public portal are retained by the authors and/or other copyright owners and it is a condition of accessing publications that users recognise and abide by the legal requirements associated with these

- Users may download and print one copy of any publication from the public portal for the purpose of private study or research.

- You may not further distribute the material or use it for any profit-making activity or commercial gain

If the publication is distributed under the terms of Article $25 \mathrm{fa}$ of the Dutch Copyright Act, indicated by the "Taverne" license above, 


\section{AANSLUITING OPLEIDING-WERK EN ARBEIDS-}

MARKTPOSITIE VAN CIVIEL-INGENIEURS

ROA-R-1993/3

G.W.M. Ramaekers

R.J.P. Dekker

RESEARCHCENTRUM VOOR ONDERWIJS EN ARBEIDSMARKT

Faculteit der Economische Wetenschappen

Rijksuniversiteit Limburg

Maastricht, mei 1993 
CIP-GEGEVENS KONINKLIJKE BIBLIOTHEEK, DEN HAAG

Ramaekers, G.W.M.

Aansluiting opleiding-werk en arbeidsmarktpositie van civiel-ingenieurs / G.W.M. Ramaekers, R.J.P. Dekker. - Maastricht: Researchcentrum voor Onderwijs en Arbeidsmarkt, Faculteit der Economische Wetenschappen, Rijksuniversiteit Limburg. - Tab. - (ROA-R-1993/3)

Met lit. opg.

ISBN 90-5321-101-2

Trefw.: arbeidsmarkt; civiele ingenieurs / onderwijs en arbeidsmarkt; Nederland. 


\section{INHOUDSOPGAVE}

Bladzijde

VERANTWOORDING

1. INLEIDING 1

1.1. Doelstelling van het onderzoek 1

1.2. Dataverzameling en representativiteit 1

1.3. Leeswijzer 3

2. KENMERKEN VAN DE RESPONDENTEN 5

3. OORDEEL OVER DE STUDIE CIVIELE TECHNIEK

3.1. Kwalificering van de opleiding 8

3.2. Oordeel over onderdelen van het studieprogramma 11

$\begin{array}{ll}\text { 3.2.1. Opbouw van het studieprogramma } & 11\end{array}$

3.2.2. Oordeel over basisstudie, projectonderwijs en afstudeerproject 11

$\begin{array}{ll}\text { 3.3. Samenvatting } & 16\end{array}$

4. ARBEIDSMARKTLOOPBAAN NA AFSTUDEREN 18

4.1. Arbeidsmarktpositie 18

4.2. Baanmobiliteit 20

4.3. Ervaringen van vrouwelijke civiel-ingenieurs 21

4.4. Samenvatting 22

5. BAANKENMERKEN 23

5.1. Dienstverband, aanstelling en arbeidsduur 23

5.2. Beroep en werkorganisatie 25

$\begin{array}{ll}\text { 5.3. Functievereisten } & 27\end{array}$

5.4. Leidinggeven en inkomen 30

5.5. Samenvatting 32

6. OORDEEL OVER DE AANSLUITING TUSSEN DE GEVOLGDE STUDIE 33

EN DE HUIDIGE FUNCTIE

6.1. Inleiding 33

6.2. Belang van kennisgebieden en vaardigheden 33

6.3. Oordeel over de aansluiting 35

6.4. Behoefte aan bijscholing 36

6.5. Samenvatting 37

7. SAMENVATTING 41

LITERATUUR

BIJLAGE 1. TABELLEN 46

BIJLAGE 2. VRAGENLIJST 


\section{VERANTWOORDING}

In 1993 wordt het onderwijs van de Faculteit der Civiele Techniek van de TU Delft beoordeeld door de visitatiecommissie 'Civiele Techniek, Bouwkunde en Geodesie'. In dit kader heeft het Bestuur van de Faculteit der Civiele Techniek een onderzoek laten verrichten naar de aansluiting opleiding-werk en de arbeidsmarktpositie van afgestudeerden van de eerstefase-opleiding Civiele Techniek. De hiervoor benodigde gegevens zijn verkregen door middel van een schriftelijke enquête onder oud-studenten die in de periode 1986-1991 aan de Faculteit der Civiele Techniek zijn afgestudeerd.

In dit onderzoek heeft het Bureau Onderwijs en Onderzoek van de Faculteit der Civiele Techniek gezorgd voor de mailing en de administratie van de enquête. De verwerking en de analyse van de enquêtegegevens, alsmede het opstellen van de rapportage is uitgevoerd door het Researchcentrum voor Onderwijs en Arbeidsmarkt van de Rijksuniversiteit Limburg. Vanuit het Bureau Onderwijs en Onderzoek heeft ir. T. Grondsma in het project geparticipeerd. Van de zijde van het Researchcentrum voor Onderwijs en Arbeidsmarkt participeerden drs. R.J.P. Dekker, A.M. Kleijnen en drs. G.W.M. Ramaekers (projectleider), daarbij wetenschappelijk ondersteund door dr. R.K.W. van der Velden. 


\section{INLEIDING}

\subsection{Doelstelling van het onderzoek}

Het Researchcentrum voor Onderwijs en Arbeidsmarkt (ROA) heeft in opdracht van het Ministerie van Onderwijs en Wetenschappen een instrument ontwikkeld voor het periodiek monitoren door universiteiten van de arbeidmarktpositie van hun afgestudeerden (Van Dam, Heijke \& Ramaekers, 1989). Het onderzoekinstrument wordt sinds een paar jaar toegepast door de Rijksuniversiteit Limburg (Ramaekers \& Heijke, 1991), terwijl de mogelijkheden worden verkend voor invoering aan andere universiteiten. In het voorjaar van 1990 heeft de HBO-Raad het ROA opdracht gegeven om dit instrument, in samenwerking met het Servicebureau Schoolverlatersinformatie (Servicebureau) te Amsterdam, nader uit te werken en toe te passen voor afgestudeerden van het $\mathrm{HBO}^{1}$.

De kern van het onderzoekinstrument wordt gevormd door een schriftelijke enquête waarbij aan afgestudeerden een aantal vragen wordt voorgelegd over: achtergrondkenmerken van de afgestudeerde, de gevolgde vooropleiding, de studie waarin men is afgestudeerd, eventuele werken bestuurservaring, verrichte activiteiten na het verlaten van de opleiding, verloop van de arbeidsmarktintrede en huidige arbeidsmarktpositie, de eventuele huidige functie en het bedrijf waarin men werkzaam is, eventuele vervolgopleidingen, de aansluiting tussen de gevolgde studierichting en de huidige functie en de bijscholingsbehoefte. De definitie en classificatie van de variabelen sluit waar mogelijk aan bij de gangbare indelingen die worden gehanteerd door het Centraal Bureau voor de Statistiek.

In het najaar van 1992 heeft het bestuur van de Faculteit der Civiele Techniek van de TU Delft het ROA opdracht gegeven om dit instrument in samenwerking met het Bureau Onderwijs en Onderzoek van de Faculteit der Civiele Techniek nader uit te werken en toe te passen in een onderzoek naar de arbeidsmarktpositie en de aansluiting opleiding-werk van afgestudeerden van de eerstefase-opleiding Civiele Techniek. Dit gebeurt in het kader van het bezoek dat de visitatiecommissie 'Civiele Techniek, Bouwkunde en Geodesie' in 1993 aan de Faculteit der Civiele Techniek brengt ${ }^{2}$.

\subsection{Dataverzameling en representativiteit}

De onderzoeksgroep bestaat in beginsel uit alle oud-studenten die in de periode oktober 1986

1. Van de Loo, Ramaekers, van der Velden, 1992.

2. Voor de beoordeling van de kwaliteit van het wetenschappelijk onderwijs heeft de Vereniging van Samenwerkende Nederlandse Universiteiten (VSNU) een systeem van visitatiecommissies ingesteld. Een visitatiecommissie baseert haar oordeel onder meer op de 'zelfstudie' van een faculteit. Volgens de 'Gids voor de onderwijsvisitatie' van de VSNU dient een zelfstudie ook aandacht te schenken aan de arbeidsmarktpositie van de afgestudeerden, hun mening over de opleiding en de eisen die het afnemende veld aan de opleiding stelt (Vereniging van Samenwerkende Nederlandse Universiteiten, 1990). 
tot en met oktober 1991 een getuigschrift hebben behaald van de eerstefase-opleiding Civiele Techniek. Het gaat om in totaal 656 afgestudeerden. Van deze 656 oud-studenten zijn er 497 schriftelijk benaderd, aangezien van 497 oud-studenten actuele adressen beschikbaar waren: het Bureau Onderwijs en Onderzoek beschikte zelf over 344 actuele adressen; 153 recente adressen zijn verkregen van het Koninklijk Instituut Van Ingenieurs.

Het Bureau Onderwijs en Onderzoek van de Faculteit der Civiele Techniek heeft de uitvoering van de dataverzameling verzorgd. In eerste instantie heeft het Bureau Onderwijs en Onderzoek een lijst aangelegd van afgestudeerden. Vervolgens heeft het Bureau Onderwijs en Onderzoek de vragenlijsten met een begeleidende brief naar de afgestudeerden gezonden, vergezeld van het verzoek om de ingevulde vragenlijsten naar het Bureau te retourneren. Circa drie weken later heeft het Bureau een rappèl gestuurd aan degenen die op dat moment nog niet hadden gereageerd. Hierbij dient te worden opgemerkt dat de 153 oud-studenten in het bestand van het Koninklijk Instituut Van Ingenieurs slechts énmaal zijn benaderd. De bovengenoemde activiteiten hebben er uiteindelijk toe geleid dat bij de start van de analyse 266 van de 497 aangeschreven oud-studenten hadden gerespondeerd, ofwel $54 \%$.

Een indicatie voor de mate waarin de uiteindelijk geënquêteerde populatie van 266 oudstudenten representatief is voor de totale populatie van 656 afgestudeerden kan worden verschaft door de verdeling naar afstudeerjaar en afstudeerrichting. Tabel 1.1 geeft een indruk van de representativiteit van de enquête naar afstudeerjaar.

Tabel 1.1. Representativiteit van de enquête naar afstudeerjaar

\begin{tabular}{|c|c|c|c|c|c|c|}
\hline & \multicolumn{2}{|c|}{ Afgestudeerden * } & \multicolumn{2}{|c|}{ Aangeschrevenen } & \multicolumn{2}{|c|}{ Respondenten } \\
\hline 1986 & 2 & $0 \%$ & 2 & $0 \%$ & 2 & $1 \%$ \\
\hline 1987 & 32 & $5 \%$ & 22 & $4 \%$ & 9 & $3 \%$ \\
\hline 1988 & 147 & $22 \%$ & 112 & $23 \%$ & 60 & $23 \%$ \\
\hline 1989 & 174 & $27 \%$ & 124 & $25 \%$ & 72 & $27 \%$ \\
\hline 1990 & 152 & $23 \%$ & 114 & $23 \%$ & 52 & $20 \%$ \\
\hline 1991 & 149 & $23 \%$ & 123 & $25 \%$ & 71 & $27 \%$ \\
\hline Totaal & 656 & $100 \%$ & 497 & $100 \%$ & 266 & $100 \%$ \\
\hline
\end{tabular}

* Bron: Bureau Onderwijs en Onderzoek, Faculteit der Civiele Techniek

Wat de verdeling naar afstudeerjaar betreft, komt de geënquêteerde populatie redelijk goed overeen met de totale populatie (tabel 1.1). De geringe afwijkingen hangen samen met zowel selectiviteit in het geactualiseerde adressenbestand als selectiviteit in de respons.

Niet alleen wat de verdeling naar afstudeerjaar betreft maar ook wat de verdeling naar afstudeerrichting betreft, komt de geënquêteerde populatie goed overeen met de totale populatie. In tabel $1.2 \mathrm{komt}$ naar voren dat met name oud-studenten Offshore technologie ondervertegenwoordigd zijn in de enquête. Hierbij dient te worden opgemerkt dat de verdeling 
naar afstudeerrichting uiteraard alleen een indicatie vormt voor de representativiteit van de onderzochte populatie als geheel. Het zegt niets over de representativiteit van de afzonderlijke afstudeerrichting-populaties.

Tabel 1.2. Representativiteit van de enquête naar afstudeerrichting

\begin{tabular}{lrrrr}
\hline & Afgestudeerden* & \multicolumn{2}{c}{ Respondenten } \\
\hline M\&C & 152 & $23 \%$ & 59 & $22 \%$ \\
WB & 134 & $20 \%$ & 56 & $21 \%$ \\
OT & 60 & $9 \%$ & 13 & $5 \%$ \\
UB & 44 & $7 \%$ & 20 & $8 \%$ \\
G\&W & 98 & $15 \%$ & 46 & $17 \%$ \\
VK & 63 & $10 \%$ & 25 & $9 \%$ \\
POO & 103 & $16 \%$ & 45 & $17 \%$ \\
overig & 2 & $0 \%$ & 2 & $1 \%$ \\
Totaal & 656 & $100 \%$ & 266 & $100 \%$ \\
\hline
\end{tabular}

* Bron: Bureau Onderwijs en Onderzoek, Faculteit der Civiele Techniek

M\&C : Mechanica \& constructies

WB : Waterbouwkunde

OT : Offshoretechnologie

UB : Utiliteitsbouw

G\&W : Gezondheidstechniek \& waterbeheersing

VK : Verkeersbouwkunde \& verkeerskunde

POO : Planning, ontwerpen \& organisatie

\subsection{Leeswijzer}

In hoofdstuk 2 wordt een beschrijving gegeven van enkele achtergrondkenmerken van de afgestudeerden. Hun oordeel over de opleiding Civiele Techniek komt in hoofdstuk 3 aan bod. Hoofdstuk 4 gaat nader in op de maatschappelijke positie na het afstuderen, de eventuele doorstroom naar vervolgonderwijs, de baanmobiliteit van de afgestudeerden en de specifieke ervaringen van vrouwelijke civiel-ingenieurs bij de beroepsuitoefening. Hoofdstuk 5 presenteert een aantal kenmerken van de functie die de afgestudeerden bekleden, alsmede van het bedrijf of de instelling waar ze werkzaam zijn. Hoofdstuk 6 gaat in op het oordeel van de afgestudeerden over de aansluiting tussen de gevolgde studierichting en de huidige functie en op de door hen aangegeven bijscholingsbehoefte. leder hoofdstuk wordt steeds afgesloten met een samenvatting van de desbetreffende onderzoeksbevindingen. In hoofdstuk 7 worden de belangrijkste resultaten van het gehele onderzoek samengevat.

Als algemene opmerking vooraf is het nuttig om erop te wijzen dat in de tabellen uitsluitend de aantallen respondenten zijn opgegeven die een vraag daadwerkelijk beantwoord hebben. Dit betekent dat degenen die een vraag niet hebben ingevuld bij de berekening van de totalen en percentages buiten beschouwing zijn gelaten. Het kan voorkomen dat de percentages door afronding niet altijd tot $100 \%$ optellen. Onder de tabellen staat, indien van toepassing, 
$-4-$

aangegeven of de verschillen die tussen de afstudeerrichtingen worden geconstateerd, significant zijn. Bij verschillen in frequenties gebeurt dit met behulp van een chi-kwadraat toets ${ }^{3}$; bij verschillen in gemiddelden met behulp van een F-toets ${ }^{4}$.

3. Deze toets geeft aan in hoeverre de geobserveerde frequenties in een tabel afwijken van de frequenties die worden verwacht indien er geen verschillen zijn tussen de afstudeerrichtingen. De bijbehorende $p$-waarde geeft de kans aan dat de gevonden verschillen op toeval berusten. Indien deze kans kleiner is dan 0.05 is er sprake van significante, dit wil zeggen niet toevallige, verschillen tussen de afstudeerrichtingen. Indien de verschillen niet significant zijn, wil dit niet zeggen dat één bepaalde afstudeerichting niet afwijkt van de andere afstudeerrichtingen. Om dit laatste te toetsen, zou er per tabel over 7 toetsen moeten worden gerapporteerd. Omwille van de overzichtelijkheid is hiervan afgezien.

4. De F-toets geeft aan in hoeverre de gemiddelde score van de desbetreffende subpopulatie afwijkt van de gemiddelde score van de totale populatie. Een bijbehorende p-waarde kleiner dan 0.05 geeft aan dat de geconstateerde afwijking niet op toeval berust en daarmee significant is. Net als bij de Chi-kwadraat toets is niet steeds gekeken naar significante afwijkingen van de afzonderlijke afstudeerrichtingen. 


\section{KENMERKEN VAN DE RESPONDENTEN}

In dit hoofdstuk worden de respondenten eerst getypeerd aan de hand van twee persoonskenmerken, namelijk het geslacht en de leeftijd (in het jaar van afstuderen). Daarna komt de opleiding aan bod.

\section{Geslacht}

De opleiding Civiele Techniek is een typische 'mannenstudie': 95\% van de respondenten bestaat uit mannen. De afstudeerrichtingen verschillen niet significant met betrekking tot de aandelen van mannen en vrouwen ${ }^{5}$.

\section{Leeftijd}

De gemiddelde leeftijd bij het afstuderen bedraagt 25.4 jaar (standaardafwijking 2.2 jaar). De afstudeerrichtingen verschillen niet significant met betrekking tot de gemiddelde leeftijd van de afstudeerders ${ }^{6}$. De grootste leeftijdsverschillen doen zich voor onder afgestudeerden Utiliteitsbouw (standaardafwijking 3.6 jaar). Afstudeerders Offshoretechnologie ontlopen elkaar qua leeftijd het minst (standaardafwijking 1.0 jaar).

\section{Vooropleiding}

Nagegaan is op grond van welke vooropleiding men toegelaten is tot de studie Civiele Techniek. In tabel 2.1 komt naar voren dat bijna $90 \%$ van de respondenten afkomstig was uit het VWO; circa $10 \%$ had eerst een HBO-opleiding gevolgd. Oud-studenten Mechanica \& constructies en Planning, ontwerpen \& organisatie zijn significant vaker dan andere civiel-ingenieurs afkomstig van de HTS.

Tabel 2.1. Vooropleiding (in \%)

\begin{tabular}{|c|c|c|c|c|c|c|c|c|}
\hline & M\&C & WB & OT & UB & G\&W & VK & POO & Tot \\
\hline HTS & 20 & 4 & & 5 & 4 & & 24 & 11 \\
\hline VWO & 78 & 95 & 92 & 95 & 89 & 96 & 71 & 86 \\
\hline Overig & 2 & 2 & 8 & & 7 & 4 & 4 & 3 \\
\hline Totaal n (=100\%) & 59 & 56 & 13 & 20 & 46 & 25 & 45 & 264 \\
\hline
\end{tabular}

$\mathrm{Chi}^{2}=28.8 ;$ d.f. $=12 ; \mathrm{P}<0.01$

\footnotetext{
5. $\quad$ Chi-kwadraat $=9.7 ;$ d.f. $=6 ; p=0.14$.

6. $F=1.8 ;$ d.f. $=7 ; p=0.08$.
} 
Hoe men achteraf de aansluiting tussen de genoten vooropleiding en de propedeuse Civiele Techniek beoordeelt, wordt weergegeven in tabel 2.2. De tabel laat zien dat vrijwel alle respondenten de aansluiting positief beoordelen: ruim driekwart van de respondenten kwalificeert de aansluiting zelfs als 'goed'. Slechts $4 \%$ had een negatief oordeel over de aansluiting.

Tabel 2.2. Oordeel over aansluiting vooropleiding-propedeuse Civiele Techniek (in \%)

$\begin{array}{lr}\text { aansluiting is goed } & 77 \\ \text { aansluiting is redelijk } & 20 \\ \text { aansluiting is matig } & 3 \\ \text { aansluiting is slecht } & 1 \\ \text { Totaal } n(=100 \%) & 266\end{array}$

Studenten met een verschillend vooropleidingstraject blijken niet verschillend te denken over de aansluiting van hun vooropleiding met de propaedeuse Civiele Techniek: VWO'ers en HBO'ers zijn gelijkluidend in hun oordeel over de aansluiting'. Er is ook nagegaan of het oordeel over de aansluiting wellicht samenhangt met de keuze van de afstudeerrichting. Dit blijkt over alle afstudeerrichtingen genomen niet het geval te $z i j n^{8}$. Dit laat onverlet dat oud-studenten Planning, ontwerpen \& organisatie $(64 \%)$ minder dan gemiddeld $(77 \%)$ de aansluiting als 'goed' kwalificeerden.

\section{Studieduur}

De respondenten hebben gemiddeld 5.9 jaar (standaardafwijking 0.9 jaar) over de opleiding Civiele Techniek gedaan. De afstudeerrichtingen verschillen niet significant met betrekking tot de gemiddelde studieduur ${ }^{\circ}$. De grootste verschillen in studieduur doen zich voor onder afgestudeerden Planning, ontwerpen \& organisatie (standaardafwijking 1.1 jaar).

HTS'ers doen gemiddeld 1 jaar korter over de studie Civiele Techniek dan VWO'ers. Oudstudenten, afkomstig van de HTS, hebben gemiddeld 5.1 jaar nodig gehad om de studie Civiele Techniek te voltooien, tegen 6.1 jaar bij oud-studenten met een VWO-vooropleiding. Dit verschil in gemiddelde studieduur is significant ${ }^{10}$, en hangt samen met het feit dat HTS'ers in het tweede studiejaar kunnen instromen.

\section{Samenvatting}

Samenvattend kan de onderzochte populatie van civiel-ingenieurs als volgt worden getypeerd:

\footnotetext{
7. Chi-kwadraat $=0.6 ;$ d.f. $=3 ; p=0.90$.

8. Chi-kwadraat $=28.1$; d.f. $=18 ; p=0.06$.

9. $F=1.5 ;$ d.f. $=6 ; p=0.16$.

10. $F=20.1 ;$ d.f. $=1 ; p<0.01$.
} 
- geslacht: mannelijk (95\%);

- vooropleiding: VWO (86\%);

- positief oordeel over aansluiting vooropleiding-propaedeause Civiele Techniek (96\%);

- gemiddelde studieduur: 5.9 jaar (met een HTS-vooropleiding: 5.1 jaar);

- gemiddelde leeftijd bij afstuderen: 25.4 jaar.

Verschillen tussen afstudeerrichtingen doen zich alleen voor met betrekking tot de vooropleiding. Oud-studenten Mechanica \& constructies en Planning, ontwerpen \& organisatie zijn significant vaker dan andere civiel-ingenieurs afkomstig van de HTS. 


\section{OORDEEL OVER DE STUDIE CIVIELE TECHNIEK}

\subsection{Kwalificering van de opleiding}

Het centrale thema van dit hoofdstuk betreft de wijze waarop civiel-ingenieurs terugkijken op hun opleiding. Eerst wordt in paragraaf 3.1 beschreven hoe men de opleiding achteraf kwalificeert. Dit gebeurt aan de hand van een zestal beoordelingscriteria. Vervolgens wordt in paragraaf 3.2 nader ingegaan op de beoordeling van een drietal onderdelen van het studieprogramma. In paragraaf 3.3 worden de belangrijkste onderzoeksbevindingen samengevat.

Aan de respondenten is gevraagd om de opleiding Civiele Techniek te beoordelen aan de hand van de moeilijkheidsgraad, het eindniveau, het aantal af te leggen tentamens, de gerichtheid van de opleiding op feitenkennis versus basiskennis en op theorie versus de toepassing ervan. Tevens is gevraagd om de door hen gekozen afstudeerrichting te beoordelen naar mate van specialisatie.

\section{Moeilijkheidsgraad van de opleiding}

De meeste oud-studenten ( $83 \%$ ) vinden de opleiding Civiele Techniek over het geheel genomen redelijk te doen; $11 \%$ vindt de opleiding achteraf gezien gemakkelijk. Dat de opleiding over het geheel genomen moeilijk was, oordeelt $6 \%$. Hierbij hebben zich geen significante verschillen tussen de afstudeerrichtingen voorgedaan ${ }^{11}$. Het oordeel over de moeilijkheidsgraad hangt evenmin samen met de genoten vooropleiding ${ }^{12}$. Wel is gebleken dat studenten die langer dan gemiddeld over de studie hebben gedaan de studie vaker als moeilijk $(14 \%)$ dan als gemakkelijk (3\%) kwalificeren in tegenstelling tot studenten die gemiddeld of korter dan gemiddeld over de studie hebben gedaan. Deze kwalificeren de studie vaker als gemakkelijk $(13 \%)$ dan als moeilijk $(4 \%)^{13}$.

\section{Eindniveau van de opleiding}

Zo eensluidend oud-studenten zijn in hun oordeel over de moeilijkheidsgraad van de opleiding, zo verdeeld zijn zij over het eindniveau na de vierjarige cursusduur. De ene helft $(52 \%)$ vindt het eindniveau precies goed, terwijl de andere helft (48\%) het eindniveau te laag vindt. Overigens vond niemand het eindniveau te hoog. Ook bij de beoordeling van dit item zijn de gevonden verschillen tussen de afstudeerrichtingen niet significant ${ }^{14}$. Het oordeel over het eindniveau verschilt evenmin naar gelang de vooropleiding ${ }^{15}$ en de vraag of men langer of korter dan

\footnotetext{
11. Chi-kwadraat $=10.5 ;$ d.f. $=12 ; p=0.57$.

12. Chi-kwadraat $=1.6$; d.f. $=2 ; p=0.44$.

13. Chi-kwadraat $=10.9 ;$ d.f. $=2 ; p<0.01$.

14. Chi-kwadraat $=6.3$; d.f. $=6 ; p=0.39$.

15. Chi-kwadraat $=1.3 ;$ d.f. $=1 ; p=0.26$.
} 
gemiddeld over de studie heeft gedaan ${ }^{16}$. Een samenhang tussen het oordeel over de moeilijkheidsgraad en het oordeel over het eindniveau kon evenmin worden vastgesteld ${ }^{17}$.

\section{Aantal tentamens}

In het derde studiejaar moeten ongeveer 20 tentamens worden afgelegd, en in de eerste helft van het vierde jaar ongeveer 10 . Ongeveer driekwart $(76 \%)$ van de respondenten vindt het aantal af te leggen tentamens precies goed. De meerderheid is dus van mening dat de leerstof, tenminste wat het aantal tentamens betreft, evenwichting wordt getoetst. Circa eenvijfde $(18 \%)$ vindt dat de leerstof te versnipperd wordt getoetst: het aantal tentamens is volgens hen te groot. Slechts $7 \%$ vindt het aantal tentamens te klein. Ten aanzien van dit kenmerk zijn verschillen tussen afstudeerrichtingen niet significant ${ }^{18}$.

\section{Gerichtheid op inzicht en feitenkennis}

De gerichtheid van de opleiding op enerzijds inzicht en anderzijds feitenkennis is volgens exact driekwart van de respondenten in evenwicht. Eenvijfde vindt dat de opleiding te veel op feitenkennis is gericht. Een kleine minderheid $(5 \%)$ is van mening dat de opleiding te veel op inzicht is gericht.

Tabel 3.1. Oordeel over de gerichtheid van de opleiding op inzicht en feitenkennis (in \%)

\begin{tabular}{|c|c|c|c|c|c|c|c|c|}
\hline & M\&C & WB & OT & UB & G\&W & VK & POO & Tot \\
\hline In evenwicht & 83 & 70 & 85 & 68 & 82 & 72 & 67 & 75 \\
\hline Te veel nadruk op inzicht & 2 & 7 & & 21 & 2 & 16 & & 5 \\
\hline Te veel nadruk op feitenkennis & 15 & 23 & 15 & 11 & 16 & 12 & 33 & 20 \\
\hline Totaal n (=100\%) & 59 & 56 & 13 & 19 & 44 & 25 & 45 & 261 \\
\hline
\end{tabular}

$\mathrm{Chi}^{2}=28.7 ;$ d.f. $=12 ; \mathrm{P}<0.01$

Bij iedere afstudeerrichting kan worden geconstateerd dat de meeste oud-studenten vinden dat de gerichtheid van de opleiding Civiele Techniek op inzicht en feitenkennis in evenwicht is (tabel 3.1). In tabel 3.1 komt echter naar voren dat oud-studenten Utiliteitsbouw en Verkeersbouwkunde \& verkeerskunde vaker dan anderen van mening zijn dat in de opleiding te veel nadruk wordt gelegd op inzicht. Daarentegen vinden oud-studenten Planning, ontwerpen \& organisatie vaker dan anderen dat de opleiding te zeer op feitenkennis is gericht.

16. Chi-kwadraat $=1.3 ;$ d.f. $=1 ; p=0.25$.

17. Chi-kwadraat $=1.1 ;$ d.f. $=2 ; p=0.59$.

18. Chi-kwadraat $=11.8 ;$ d.f. $=12 ; p=0.46$. 


\section{Verhouding tussen theorie en praktijk}

Oud-studenten zijn verdeeld in hun oordeel over de wijze waarop in de opleiding theorie en de praktische toepassing ervan aan bod komen. lets meer dan de helft $(52 \%)$ is van mening dat in de opleiding te veel nadruk wordt gelegd op theorie. lets minder dan de helft (47\%) vindt dat er sprake is van een evenwichtige verhouding tussen theorie en praktijk. Vrijwel niemand $(2 \%)$ vindt dat er te veel nadruk op de praktische toepassing van theorie wordt gelegd. Ten aanzien van dit item doen zich geen significante verschillen tussen de afstudeerrichtingen voor ${ }^{19}$.

\section{Specialisatie van afstudeerrichtingen}

De meeste oud-studenten (76\%) vinden dat de door hen gekozen afstudeerrichting voldoende gespecialiseerd is. Circa eenvijfde vindt dat de gekozen afstudeerrichting te algemeen is. Vrijwel niemand $(3 \%)$ vindt de gekozen afstudeerrichting te specialistisch.

Tabel 3.2. Oordeel over specialisatie van de afstudeerrichtingen (in \%)

\begin{tabular}{|c|c|c|c|c|c|c|c|c|}
\hline & $M \& C$ & WB & OT & UB & G\&W & VK & POO & Tot \\
\hline $\begin{array}{l}\text { Richting is voldoende } \\
\text { gespecialiseerd }\end{array}$ & 90 & 89 & 67 & 65 & 81 & 63 & 51 & 76 \\
\hline Richting is te algemeen & 3 & 11 & 25 & 25 & 16 & 33 & 50 & 21 \\
\hline Richting is te specialistisch & 7 & & 8 & 10 & 2 & 4 & & 4 \\
\hline Totaal n (=100\%) & 59 & 55 & 12 & 20 & 43 & 24 & 45 & 258 \\
\hline
\end{tabular}

$\mathrm{Chi}^{2}=47.5 ;$ d.f. $=12 ; \mathrm{PO} .01$

Bij geen enkele afstudeerrichting is de verdeeldheid onder oud-studenten zo groot als onder oudstudenten Planning, ontwerpen \& organisatie (tabel 3.2): ongeveer de helft vindt de afstudeerrichting voldoende gespecialiseerd; eveneens circa de helft is echter van mening dat de afstudeerrichting POO te algemeen is. Ook oud-studenten Verkeersbouwkunde \& verkeerskunde zijn vaker dan gemiddeld de mening toegedaan dat hun afstudeerrrichting te algemeen is. Van alle afgestudeerden zijn oud-studenten Mechanica \& constructies, Waterbouwkunde en Gezondheidstechniek \& waterbeheersing veruit het meest tevreden met de mate waarin hun afstudeerrichting gespecialiseerd is.

19. Chi-kwadraat $=13.6 ;$ d.f. $=12 ; p=0.33$. 


\subsection{Oordeel over onderdelen van het studieprogramma}

\subsubsection{Opbouw van het studieprogramma 20}

De eerstefase-opleiding Civiele Techniek is opgebouwd uit een gemeenschappelijk tweejarig basisprogramma, gevolgd door een gedifferentieerd tweejarig programma. In de gemeenschappelijke basisstudie, die twee jaar duurt, komen de hoofdvakken van de Civiele Techniek aan bod, namelijk constructieleer, mechanica, materiaalkunde, wiskunde, inleiding Civiele Techniek en projectoefeningen.

In het derde cursusjaar worden de hoofdrichtingen (afstudeerrichtingen) binnen Civiele Techniek gefaseerd gekozen. De vakken in het derde jaar zijn gegroepeerd in 23 pakketten: in de eerste helft van het derde jaar 8 pakketten en in de tweede helft van het derde jaar 15 pakketten. Deze pakketten betreffen zowel de uitbreiding van de basiskennis als de verschillende afstudeerrichtingen. Van deze pakketten moet de student, zowel in de eerste als in de tweede helft van het derde cursusjaar, er drie kiezen. Vanuit een afstudeerrichting kunnen, zowel in de eerste als in de tweede helft van het derde cursusjaar, maximaal twee pakketten verplicht worden voorgeschreven. Naast vakken bestaat het derde jaar ook uit (project)oefeningen die voor een deel in teamverband moeten worden uitgevoerd.

Het vierde cursusjaar bestaat voor de helft uit een afstudeerwerkstuk en voor de andere helft uit vakken, waarvan een aantal verplicht zijn voorgeschreven. Het voltooien van de eerstefaseopleiding wordt bekroond met het diploma 'Ingenieur Civiele Techniek', waarop tevens de afstudeerrichting staat vermeld.

$\mathrm{Na}$ het voltooien van de eerstefase-opleiding kan de studie worden voortgezet in een tweejarige ontwerpersopleiding of een vierjarige onderzoekersopleiding.

\subsubsection{Oordeel over basisstudie, projectonderwijs en afstudeerproject}

In de vorige paragraaf is beschreven hoe civiel-ingenieurs hun opleiding achteraf kwalificeren. Hieronder wordt nader ingegaan op hun oordeel over drie onderdelen van het studieprogramma, namelijk de basisstudie, het projectonderwijs en het afstudeerproject.

\section{Basisstudie}

Zoals hierboven reeds is opgemerkt, komen in de gemeenschappelijke tweejarige basisstudie de hoofdvakken van de Civiele Techniek aan bod. In tabel 3.3 staat in de tweede kolom vermeld hoe de studiepunten in de basisstudie over de vijf hoofdvakken zijn verdeeld.

20. Faculteit der Civiele Techniek, TU Delft (1990), blz. 23-25. 
Aan de respondenten is gevraagd of men de studiepunten anders zou verdelen en zo ja, volgens welke verdeling. lets meer dan de helft $(52 \%)$ is tevreden over het gewicht dat in de basisstudie aan bovengenoemde hoofdgroepen wordt toegekend: men zou de studiepunten op dezelfde wijze verdelen. Bijna de helft $(48 \%)$ van de respondenten zou de studiepunten anders verdeeld willen zien.

Tabel 3.3. Feitelijke en gewenste verdeling van studiepunten in de basisstudie

Feitelijke verdeling

wiskunde

mechanica

constructieleer/materiaalkunde

algemene civiele techniek

informatica/computertoepassingen

projectonderwijs

totaal

$\begin{array}{rr}21 \% & 20 \% \\ 27 \% & 25 \% \\ 23 \% & 22 \% \\ 15 \% & 16 \% \\ 6 \% & 8 \% \\ 8 \% & 9 \% \\ 100 \% & 100 \%\end{array}$

In tabel 3.3 staat in de derde kolom vermeld hoe de gewenste verdeling van de studiepunten er uitziet. Voor respondenten die de studiepunten niet anders zouden verdelen, zijn de desbetreffende waarden van de feitelijke verdeling gebruikt bij het berekenen van de gewenste verdeling. Voor respondenten die een andere verdeling van de studiepunten voorstaan, zijn uiteraard de door hen voorgestelde percentages gebruikt bij het berekenen van de gewenste verdeling. In tabel 3.3 komt naar voren dat men bij mechanica, constructieleer/materiaalkunde en wiskunde studiepunten zou weghalen en deze aan informatica/computertoepassingen, algemene civiele techniek en projectonderwijs zou toevoegen. In zijn algemeenheid blijft de huidige verdeling echter gehandhaafd, gezien de geringe verschillen tussen de gewenste en feitelijke verdeling van de studiepunten.

Tabel 3.4. Gewenste verdeling van studiepunten in de basisstudie, naar afstudeerrichting (in \%)

\begin{tabular}{lrrrrrrrr}
\hline & M\&C & WB & OT & UB & G\&W & VK & POO \\
\hline Wiskunde & & & & & & & & \\
Mechanica" & 20 & 21 & 19 & 20 & 21 & 20 & 20 \\
Constructieleer/materiaalkunde" & 26 & 25 & 27 & 26 & 24 & 24 & 24 \\
Algemene civiele techniek" & 23 & 22 & 23 & 24 & 21 & 22 & 21 \\
Informatica/computertoepassingen & 15 & 15 & 15 & 15 & 17 & 17 & 17 \\
Projectonderwijs & 7 & 8 & 8 & 7 & 8 & 8 & 9 \\
& 8 & 9 & 8 & 9 & 10 & 9 & 10 \\
\hline
\end{tabular}

- Verschillen significant op $5 \%$ niveau

"Verschillen significant op $1 \%$ niveau 
Er zijn geen significante verschillen tussen de afstudeerrichtingen met betrekking tot het (doorgaans lager) aantal studiepunten dat oud-studenten aan wiskunde in de basisstudie zouden willen besteden, en het (doorgaans hoger) aantal studiepunten dat men aan informatica/computertoepassingen of projectonderwijs zou besteden. De afstudeerrichtingen verschillen wel significant ten aanzien van het aantal studiepunten dat oud-studenten in de basisstudie aan mechanica, constructieleer/materiaalkunde en algemene civiele techniek besteed zouden willen zien. Hiervan geeft tabel 3.4 een beeld.

Aan mechanica zouden oud-studenten Offshoretechnologie $27 \%$ van de studiepunten willen besteden. Dit komt overeen met het feitelijk gewicht dat mechanica in de basisstudie krijgt, namelijk $27 \%$ van de studiepunten. Oud-studenten van de andere afstudeerrichtingen zouden minder gewicht aan mechanica willen toekennen.

Oud-studenten Offshoretechnologie en Mechanica \& constructies zijn tevreden met het gewicht dat constructieleer/materiaalkunde in de basisstudie krijgt. Zij zouden, evenals feitelijk het geval is, $23 \%$ van de studiepunten aan dit onderdeel besteden. Oud-studenten van de andere afstudeerrichtingen, behoudens Utiliteitsbouw, zouden minder studiepunten besteden aan constructieleer/materiaalkunde.

Aan algemene civiele techniek zouden zowel oud-studenten Verkeersbouwkunde \& verkeerskunde als oud-studenten Planning, ontwerpen \& organisatie en oud-studenten Gezondheidstechniek \& waterbeheersing $17 \%$ van de studiepunten willen besteden. Dit is meer dan het feitelijk gewicht dat in de basisstudie aan algemene civiele techniek wordt toegekend, namelijk $15 \%$. Oud-studenten van de andere afstudeerrichtingen (Waterbouwkunde, Mechanica \& constructies, Utiliteitsbouw en Offshoretechnologie) zijn tevreden met het gewicht dat algemene civiele techniek in de basisstudie krijgt. Zij zouden eveneens $15 \%$ van de studiepunten aan algemene civiele techniek besteden.

\section{Projectonderwijs}

In de eerste drie cursusjaren worden in totaal 10 werkweken uitgetrokken voor projectonderwijs. Ongeveer de helft $(52 \%)$ van de respondenten vindt 10 werkweken voor projectonderwijs voldoende. Eenderde $(33 \%)$ is van mening dat voor projectonderwijs meer werkweken mogen worden uitgetrokken. Volgens $15 \%$ van de respondenten zijn 10 werkweken voor projectonderwijs al te veel. Hierbij hebben zich geen significante verschillen tussen de afstudeerrichtingen voorgedaan ${ }^{21}$.

In het projectonderwijs komen onder meer de volgende aspecten aan bod:

- ontwerpen en construeren;

- toepassen van theorie in de praktijk;

- onderzoeksvaardigheden;

21. Chi-kwadraat $=13.8 ;$ d.f. $=12 ; p=0.31$. 
- schriftelijk presenteren;

- mondeling presenteren.

Aan de respondenten is de vraag voorgelegd of aan bovengenoemde aspecten meer, evenveel of minder aandacht moet worden besteed.

Ten aanzien van de volgende aspecten overheerst de mening dat aan het desbetreffende aspect voldoende aandacht is besteed: ontwerpen en construeren, onderzoeksvaardigheden en schriftelijk presenteren. Met betrekking tot het toepassen van theorie in de praktijk en mondeling presenteren overheerst de mening dat hieraan best meer aandacht zou mogen worden besteed (tabel 3.5).

Tabel 3.5. Gewenste aandacht voor aspecten projectonderwijs (in \%)

\begin{tabular}{lllcl}
\hline & $\begin{array}{l}\text { meer } \\
\text { aandacht }\end{array}$ & $\begin{array}{l}\text { evenveel } \\
\text { aandacht }\end{array}$ & $\begin{array}{l}\text { minder } \\
\text { aandacht }\end{array}$ & $\begin{array}{l}\text { totaal } n \\
(=100 \%)\end{array}$ \\
\hline Ontwerpen en construeren & 32 & 57 & 12 & 260 \\
Toepassen theorie in praktijk & 62 & 37 & 2 & 261 \\
Onderzoeksvaardigheden & 33 & 51 & 16 & 261 \\
Schriftelijk presenteren & 35 & 56 & 8 & 260 \\
Mondeling presenteren & 48 & 45 & 7 & 261 \\
\hline
\end{tabular}

Significante verschillen tussen de afstudeerrichtingen hebben zich alleen voorgedaan met betrekking tot het aspect ontwerpen en construeren en het aspect onderzoeksvaardigheden. Oud-studenten Utiliteitsbouw en Offshoretechnologie zijn meer dan gemiddeld van mening dat in het projectonderwijs meer aandacht moet worden besteed aan ontwerpen en construeren (tabel 3.6).

Tabel 3.6. Gewenste aandacht voor 'ontwerpen en construeren' in projectonderwijs (in \%)

\begin{tabular}{lrrrrrrrr}
\hline & M\&C & WB & OT & UB & G\&W & VK & POO & Tot \\
\hline Meer aandacht & 31 & 35 & 46 & 68 & 18 & 17 & 31 & 32 \\
Evenveel aandacht & 63 & 50 & 46 & 26 & 68 & 67 & 56 & 57 \\
Minder aandacht & 7 & 15 & 8 & 5 & 14 & 17 & 13 & 12 \\
Totaal n $(=100 \%)$ & 59 & 54 & 13 & 19 & 44 & 24 & 45 & 258
\end{tabular}

$\mathrm{Chi}^{2}=22.3 ;$ d.f. $=12 ; \mathrm{P}<0.05$

Oud-studenten Verkeersbouwkunde \& verkeerskunde en Gezondheidstechniek \& waterbeheersing zijn meer dan gemiddeld van mening dat onderzoeksvaardigheden meer aandacht moeten krijgen. Oud-studenten Waterbouwkunde en Utiliteitsbouw zijn relatief vaak de mening toegedaan dat onderzoeksvaardigheden best wat minder aandacht in het projectonderwijs mogen krijgen (tabel 3.7). 
Tabel 3.7. Gewenste aandacht voor 'onderzoeksvaardigheden' in projectonderwijs (in \%)

\begin{tabular}{|c|c|c|c|c|c|c|c|c|}
\hline & $M \& C$ & WB & OT & UB & G\&W & VK & POO & Tot \\
\hline Meer aandacht & 22 & 27 & 15 & 26 & 46 & 48 & 36 & 32 \\
\hline Evenveel aandacht & 66 & 46 & 77 & 47 & 48 & 36 & 49 & 52 \\
\hline Minder aandacht & 12 & 27 & 8 & 26 & 7 & 16 & 16 & 16 \\
\hline Totaal n (=100\%) & 58 & 55 & 13 & 19 & 44 & 25 & 45 & 259 \\
\hline
\end{tabular}

$\mathrm{Chi}^{2}=22.6 ;$ d.f. $=12 ; \mathrm{P}<0.05$

\section{Afstudeerproject}

Oud-studenten hebben hun afstudeerproject vaker buiten de Faculteit der Civiele Techniek verricht $(56 \%)$ dan binnen (een onderzoeksproject van) de faculteit $(44 \%)$. Bij de afstudeerrichtingen Verkeersbouwkunde \& verkeerskunde, Waterbouwkunde en Mechanica \& constructies worden de meeste afstudeerprojecten binnen de Faculteit der Civiele Techniek verricht: Verkeersbouwkunde \& verkeerskunde $60 \%$, Waterbouwkunde $57 \%$ en Mechanica \& constructies $52 \%$. Bij de afstudeerrichtingen Planning, ontwerpen \& organisatie, Gezondheidstechniek \& waterbeheersing, Offshoretechnologie en Utiliteitsbouw worden de meeste afstudeerprojecten buiten de Faculteit der Civiele Techniek verricht: Planning, ontwerpen \& organisatie $71 \%$, Gezondheidstechniek \& waterbeheersing $69 \%$, Offshoretechnologie $62 \%$ en Utiliteitsbouw $60 \%$ buiten de faculteit ${ }^{22}$.

De meerderheid $(65 \%)$ is van mening dat een half jaar voor een afstudeerproject te kort is. Circa een derde $(35 \%)$ vindt een half jaar voor dit doel precies genoeg. Niemand vond dat een half jaar te lang was. Hierbij hebben zich geen significante verschillen tussen de afstudeerrichtingen voorgedaan ${ }^{23}$.

Circa driekwart van de respondenten is tevreden over de begeleiding die men tijdens het verrichten van het afstudeerproject heeft gekregen: men vond de begeleiding redelijk $(30 \%)$ of goed $(43 \%)$. Circa een kwart van de oud-studenten is ontevreden over de begeleiding: men vond de begeleiding maar matig $(18 \%)$ of zelfs slecht $(9 \%)$. Ook hierbij hebben zich geen significante verschillen tussen de afstudeerrichtingen voorgedaan ${ }^{24}$.

In tabel 3.8 komt naar voren dat $7 \%$ van alle respondenten het afstudeerproject in het buitenland heeft verricht. Oud-studenten Gezondheidstechniek \& waterbeheersing hebben vaker dan gemiddeld hun afstudeerproject in het buitenland uitgevoerd. Indien geschikte afstudeerprojecten in het buitenland beschikbaar waren geweest, zou de meerderheid van de oud-studenten

22. Chi-kwadraat $=15.3 ;$ d.f. $=6 ; p<0.05$.

23. Chi-kwadraat $=6.8 ;$ d.f. $=12 ; p=0.34$.

24. Chi-kwadraat $=18.1 ;$ d.f. $=18 ; p=0.45$. 
(53\%) daarvan gebruik hebben gemaakt; $40 \%$ zou dit niet hebben gedaan (tabel 3.8, laatste kolom). Met name oud-studenten Waterbouwkunde zouden van geschikte afstudeerprojecten in het buitenland gebruik hebben gemaakt.

Tabel 3.8. Gebruik van afstudeerprojectmogelijkheden in het buitenland, indien deze beschikbaar waren geweest (in \%)

\begin{tabular}{|c|c|c|c|c|c|c|c|c|}
\hline & $M \& C$ & WB & OT & UB & G\&W & VK & POO & Tot \\
\hline Nee & 48 & 27 & 39 & 45 & 46 & 44 & 36 & 40 \\
\hline $\mathrm{Ja}$ & 51 & 71 & 62 & 50 & 27 & 44 & 64 & 53 \\
\hline $\mathrm{Nvt}^{*}$ & 2 & 2 & & 5 & 27 & 12 & & 7 \\
\hline Totaal $n(=100 \%)$ & 59 & 55 & 13 & 20 & 44 & 25 & 45 & 261 \\
\hline
\end{tabular}

$\mathrm{Chi}^{2}=50.3 ;$ d.f. $=12 ; \mathrm{P}<0.01$

Overigens vindt de overgrote meerderheid $(84 \%)$ het wenselijk dat de Faculteit der Civiele Techniek afstudeerprojecten in het buitenland creëert. Hierbij doen zich geen significante verschillen tussen de afstudeerrichtingen voor ${ }^{25}$.

\subsection{Samenvatting}

\section{Kwalificering van de opleiding}

Oud-studenten zijn vrijwel eensluidend in hun oordeel over de moeilijkheidsgraad van de opleiding, het aantal af te leggen tentamens, de gerichtheid van de opleiding op inzicht versus feitenkennis en de specialisatie van de afstudeerrichtingen. De meerderheid:

- vindt de opleiding Civiele Techniek over het geheel genomen redelijk te doen (83\%);

- is tevreden over het aantal tentamens dat moet worden afgelegd (76\%);

- oordeelt dat de gerichtheid van de opleiding op enerzijds inzicht en anderzijds feitenkennis evenwichtig is $(75 \%)$;

- vindt dat de door hen gekozen afstudeerrichting (met uitzondering van Planning, ontwerpen \& organisatie) voldoende gespecialiseerd is $(76 \%)$.

Verdeeld zijn oud-studenten in hun oordeel over het eindniveau van de vierjarige opleiding en de verhouding tussen theorie en praktijk:

- de ene helft (52\%) vindt het eindniveau precies goed, terwijl de andere helft (48\%) het eindniveau te laag vindt;

- de ene helft (47\%) vindt dat er sprake is van een evenwichtige verhouding tussen theorie en praktijk, terwijl de andere helft (52\%) van mening is dat in de opleiding te veel nadruk wordt

25. Chi-kwadraat $=10.7 ;$ d.f. $=6 ; p=0.10$. 
gelegd op theorie.

\section{Basisstudie}

Als het aan oud-studenten lag, zouden bij mechanica, constructieleer/materiaalkunde en wiskunde enkele studiepunten worden weggehaald en aan informatica/computertoepassingen, algemene civiele techniek en projectonderwijs worden toegevoegd. In het algemeen wijkt de gewenste verdeling van hoofdvakken echter nauwelijks af van de feitelijke verdeling.

\section{Projectonderwijs}

Ongeveer de helft $(52 \%)$ van de respondenten vindt 10 werkweken voor projectonderwijs voldoende. Volgens een derde $(33 \%)$ mogen voor projectonderwijs meer werkweken worden uitgetrokken.

Ontwerpen en construeren, onderzoeksvaardigheden en schriftelijk presenteren komen volgens de meeste oud-studenten voldoende aan bod in het projectonderwijs. Met betrekking tot het toepassen van theorie in de praktijk en mondeling presenteren overheerst de mening dat hieraan best meer aandacht zou mogen worden besteed.

\section{Afstudeerproject}

Oud-studenten zijn in meerderheid $(65 \%)$ van mening dat een half jaar voor een afstudeerproject te kort is. Circa een derde (35\%) vindt een half jaar voor dit doel precies genoeg. Circa driekwart van de respondenten is tevreden over de begeleiding bij het afstudeerproject. De meerderheid $(84 \%)$ acht het wenselijk dat de Faculteit der Civiele Techniek afstudeerprojecten in het buitenland creëert. 


\section{ARBEIDSMARKTLOOPBAAN NA AFSTUDEREN}

\subsection{Arbeidsmarktpositie}

Deze paragraaf beschrijft eerst de intrede op de arbeidsmarkt aan de hand van de maatschappelijke positie tijdens de eerste twaalf maanden na het afstuderen. Daarna komt de huidige maatschappelijke positie aan bod, dit wil zeggen de arbeidsmarktpositie op het moment van enquêteren. De daaropvolgende paragraaf 4.2 gaat nader in op de eventuele baanmobiliteit, dit wil zeggen het veranderen van werkgever en/of van functie. Paragraaf 4.3 besteedt speciaal aandacht aan de ervaringen van werkende vrouwelijke civiel-ingenieurs.

\section{Arbeidsmarktpositie in het eerste jaar na afstuderen}

Tabel 4.1. geeft een beeld van de maatschappelijke positie van civiel-ingenieurs, gemeten éen maand, drie maanden, zes maanden en twaalf maanden na het afstuderen. Het gaat hierbij om de maatschappelijke positie die volgens de respondenten hun dagelijkse situatie in de desbetreffende maand het beste weergeeft. Onder werkloos wordt in deze tabel begrepen: 'werkzoekend, terwijl geen of minder dan 12 uur per week betaald werk wordt verricht'.

Tabel 4.1. Maatschappelijke positie in het eerste jaar na afstuderen (in \%)

\begin{tabular}{lrrrr}
\hline & \multicolumn{1}{c}{ maand na het afstuderen } & \\
& 1 & 3 & 6 & 12 \\
\hline & & & & \\
Betaald werk & 45 & 60 & 36 & 3 \\
Student & 4 & 3 & 5 & 25 \\
Werkloos & 17 & 12 & 1 & 0 \\
Militaire dienst & 12 & 18 & 0 & 0 \\
Vervangende dienst & 0 & 1 & 2 & 264 \\
Vrijwilligerswerk & 1 & 0 & 265 & \\
Overig & 21 & 6 & & \\
Totaal n (=100\%) & 265 & 265 & & \\
\hline
\end{tabular}

Bijna de helft van de oud-studenten heeft direct na het afstuderen een betaalde baan voor tenminste 12 uur per week. Het aandeel van betaald werkenden loopt op van $45 \%$ in de eerste maand na het afstuderen via $60 \%$ in de derde maand tot $67 \%$ één jaar na afstuderen. In de eerste maand na het afstuderen is er nog een hoog percentage afgestudeerden in de categorie 'anders' (vakantie). Voorts zitten in het eerste jaar na afstuderen veel afgestudeerden in militaire dienst. Wanneer alleen degenen in de beschouwing worden betrokken die zich aanbieden op de arbeidsmarkt, namelijk betaald werkenden en werklozen, ontstaat het volgende beeld. Het aandeel van werklozen, uitgedrukt als percentage van degenen die zich op de arbeidsmarkt aanbieden, bedraagt in de eerste maand na het afstuderen nog $28 \%$. Het aandeel van werklozen loopt echter snel terug, van $17 \%$ in de derde maand na afstuderen tot $7 \%$ in de zesde 
maand na afstuderen. Eén jaar na afstuderen is nog slechts $3 \%$ van degenen die zich op de arbeidsmarkt aanbieden, werkloos.

$\mathrm{Er}$ is ook nagegaan of de afstudeerrichtingen significant verschillen met betrekking tot het aandeel van werkzoekende aanbieders op de arbeidsmarkt. Dit blijkt in geen enkele periode na het afstuderen het geval te zijn.

$\mathrm{Na}$ de opleiding Civiele Techniek is $17 \%$ van de respondenten een verdere opleiding gaan volgen, waarvan $6 \%$ in het kader van een promotiebaan bij de Faculteit der Civiele Techniek. Vooral oud-studenten Mechanica \& constructies en Verkeersbouwkunde \& verkeerskunde combineren vaker dan gemiddeld werken en verder onderwijs in een promotiebaan binnen de faculteit (tabel 4.2). Oud-studenten Utiliteitsbouw en Offshoretechnologie gaan vaker dan gemiddeld andere opleidingen volgen. Afgestudeerden Waterbouwkunde kiezen vaker dan anderen niet voor verder onderwijs.

Tabel 4.2. Verdere opleidingen (in \%)

\begin{tabular}{lrrrrrrrr}
\hline & M\&C & WB & OT & UB & G\&W & VK & POO & Tot \\
\hline Geen & 83 & 91 & 77 & 75 & 82 & 84 & 80 & 83 \\
2e fase opleiding & 14 & 4 & & & 2 & 12 & 2 & 6 \\
Andere opleiding & 3 & 5 & 23 & 25 & 16 & 4 & 18 & 11 \\
Totaal n (=100\%) & 59 & 56 & 13 & 20 & 45 & 25 & 45 & 263 \\
& & & & & & & & \\
\hline
\end{tabular}

$\mathrm{Chi}^{2}=26.9 ;$ d.f. $=12 ; \mathrm{P}<0.01$

\section{Huidige arbeidsmarktpositie}

Hierboven is een beeld geschetst van de verschuivingen in maatschappelijke positie tijdens de eerste twaalf maanden na het afstuderen. Hieronder komt de huidige maatschappelijke positie aan bod, dit wil zeggen de maatschappelijke positie op het moment van enquêteren (doorgaans een tot vier jaar na het afstuderen). Tevens wordt nagegaan hoeveel respondenten thans werkloos zijn.

Aan de respondenten is gevraagd welke hoofdbezigheid hun dagelijkse situatie op het moment van enquêtering het beste weergeeft. Naar voren komt dat vrijwel alle $(92 \%)$ respondenten op het moment van de enquête minimaal 12 uur per week betaald werk verrichten; $4 \%$ is werkloos, $3 \%$ vervult (vervangende) militaire dienstplicht en $1 \%$ is student.

De werkloosheid onder civiel-ingenieurs die zich op de arbeidsmarkt aanbieden, bedraagt op het moment van enquêteren 3\%. Het gaat om in totaal 7 oud-studenten, waarvan er 5 in 1991 (dus ongeveer een jaar geleden) waren afgestudeerd. Werkloos zijn degenen die niet of minder dan 12 uur per week betaald werken, actief op zoek zijn naar betaald werk voor tenminste 12 uur 
per week en direct beschikbaar zijn voor de arbeidsmarkt. Het laatste wil zeggen dat men binnen twee weken met een betaalde baan moet kunnen beginnen. Verschillen in werkloosheid onder afgestudeerden van de verschillende afstudeerrrichtingen zijn niet significant ${ }^{28}$. Uit een enquête die 1 jaar eerder is gehouden onder afgestudeerden van het HBO, is gebleken dat de werkloosheid onder oud-HBO-studenten weg-en waterbouwkunde eveneens erg laag is ${ }^{27}$.

\subsection{Baanmobiliteit}

Bij arbeidsmobiliteit kan onderscheid worden gemaakt tussen het aantal organisaties waarin men gewerkt heeft (externe baanmobiliteit) en het aantal functies waarin men heeft gewerkt. Bij dit laatste kan ook interne baanmobiliteit een rol spelen, dit wil zeggen verandering van functie in dezelfde organisatie, bijvoorbeeld door promotie, overplaatsing of substantiële verandering van de inhoud van de werkzaamheden. Deze paragraaf beperkt zich tot degenen die na het afstuderen betaald werk gedurende minimaal 12 uur per week hebben verricht (93\% van alle respondenten). Militaire of vervangende dienstplicht is hierbij niet als betaald werk gerekend.

\section{Verandering van organisatie}

In tabel 4.3 zijn de enquêteresultaten weergegeven met betrekking tot de externe baanmobiliteit van civiel-ingenieurs en het veranderen van functie.

Tabel 4.3. Aantal organisaties en functies (in \%)

\begin{tabular}{lcc}
\hline & organisaties * & functies * \\
\hline & 58 & 33 \\
1 & 27 & 39 \\
2 & 11 & 18 \\
3 & 2 & 4 \\
5 & 1 & 1 \\
6 & 0 & 254 \\
Totaal $n$ (=100\%) & 253 & \\
\hline
\end{tabular}

Op het moment van de enquête zijn de meeste $(58 \%)$ respondenten nog niet van werkorganisatie veranderd. Dit is niet zo verwonderlijk aangezien het gaat om oud-studenten waarvan de overgrote meerderheid nog niet zo lang (een tot vier jaar) geleden is afgestudeerd. Het gemiddeld aantal organisaties waarin men heeft gewerkt (inclusief de huidige werkgever/eigen bedrijf) bedraagt in totaal 1.6 en varieert van 1.5 bij oud-studenten Verkeersbouwkunde \&

26. Chi-kwadraat $=7.6 ;$ d.f. $=6 ; p=0.27$.

27. Van de Loo, Ramaekers, van der Velden (1992). 
verkeerskunde tot $2.1 \mathrm{bij}$ oud-studenten Offshoretechnologie. De verschillen tussen de afstudeerrichtingen zijn echter niet significant ${ }^{28}$.

\section{Verandering van functie}

Zoals eerder is opgemerkt, kan arbeidsmobiliteit ook een verandering van functie inhouden. In tabel 4.3 komt naar voren dat $67 \%$ van de betaald werkende civiel-ingenieurs al eens van functie is veranderd. Het gemiddeld aantal functies dat men heeft uitgeoefend (inclusief de huidige functie) bedraagt in totaal 2.1 en varieert van 1.9 bij oud-studenten Mechanica \& constructies en oud-studenten Utiliteitsbouw tot 2.8 bij oud-studenten Offshoretechnologie. Ook hier zijn de verschillen tussen de afstudeerrichtingen niet significant ${ }^{29}$.

Van de oud-studenten die van functie zijn veranderd blijkt $39 \%$ niet van werkgever te zijn veranderd. Dit wijst erop dat functieverandering meestal gepaard gaat met verandering van werkorganisatie (externe mobiliteit). Overigens neemt het aantal organisaties waarbinnen men heeft gewerkt en het aantal uitgeoefende functies significant toe naarmate men langer is afgestudeerd: de correlatiecoëfficiënt van het aantal jaren dat men reeds is afgestudeerd met het aantal werkorganisaties bedraagt .24; de correlatiecoëfficiënt van het aantal jaren dat men reeds is afgestudeerd met het aantal uitgeoefende functies bedraagt .36 (beide coëfficiënten zijn significant op $1 \%$ niveau).

\section{Potentiële baanmobiliteit}

Hieronder komt aan bod hoe degenen die op het moment van enquêteren betaald werken hun baan beoordelen. Een indicatie hiervoor wordt gevormd door het al dan niet zoeken naar ander werk. De meeste $(87 \%)$ oud-studenten zijn blijkbaar tevreden met hun werk; zij zijn althans niet op zoek naar ander werk. Met betrekking tot betaald werkenden die wel op zoek zijn naar ander werk kan, in arbeidsmarkttermen, worden gesproken van potentiële baanmobiliteit. Met betrekking tot de potentiële baanmobiliteit blijkt $13 \%$ van de betaald werkende civiel-ingenieurs op zoek te zijn naar ander werk. Hierbij doen zich geen significante verschillen tussen de afstudeerrichtingen voor ${ }^{30}$.

\subsection{Ervaringen van vrouwelijke civiel-ingenieurs}

Eerder is er al op gewezen dat Civiele Techniek een typische mannenstudie is. Onder de 266 in de analyse meegenomen oud-studenten bevinden zich slechts 14 vrouwen, die overigens allen een betaalde baan hebben. Vanwege dit kleine aantal vrouwen zijn uitsplitsingen naar afstudeerrichting niet zinvol, en hebben de in deze paragraaf gepresenteerde resultaten slechts een

28. $F=1.2 ;$ d.f. $=6 ; p=0.33$.

29. $F=2.0 ;$ d.f. $=6 ; p=0.06$.

30. Chi-kwadraat $=5.1 ;$ d.f. $=6 ; p=0.53$. 
indicatieve waarde.

Aan de vrouwelijke oud-studenten is eerst de vraag voorgelegd of zij bij de functie-uitoefening problemen hebben ervaren om als vrouwelijke ingenieur te worden geaccepteerd. Gebleken is dat de vrouwen dergelijke problemen in de meeste functies $(82 \%)$ niet hebben ondervonden. Vervolgens is aan de vrouwelijke oud-studenten gevraagd of zij bij de functie-uitoefening problemen hebben ervaren met de combinatie carrière/ouderschap. Ook hierbij blijken vrouwen in de meeste functies $(94 \%)$ dergelijke problemen niet te ondervinden. Hierbij dient echter te worden bedacht dat het gaat om jonge vrouwen in het begin van hun beroepsloopbaan, die wellicht nog geen kind(eren) hebben.

De bevinding dat de meeste werkende vrouwen geen problemen hebben ondervonden met de acceptatie als vrouwelijke ingenieur of met de combinatie carrière/ouderschap, laat onverlet dat 8 van de 14 vrouwelijke respondenten belangstelling hebben voor (informeel) overleg tussen vrouwelijke civiel-ingenieurs.

\subsection{Samenvatting}

Civiel-ingenieurs hebben weinig problemen met het vinden van werk: het aandeel van werklozen daalt immers snel, van $17 \%$ in de derde maand na afstuderen tot $7 \%$ in de zesde maand na afstuderen. Eén jaar na afstuderen is nog slechts $3 \%$ van degenen die zich op de arbeidsmarkt aanbieden werkloos. De onderzochte civiel-ingenieurs veranderen vaker van functie $(67 \%)$ dan van werkorganisatie $(42 \%)$. Wel gaat functieverandering meestal gepaard met verandering van werkgever. De meeste civiel-ingenieurs $(87 \%)$ schijnen tevreden te zijn met hun baan; zij zijn althans niet op zoek naar ander werk. Vrouwelijke respondenten hebben doorgaans geen problemen ervaren met de acceptatie als vrouwelijke ingenieur of met de combinatie carrière/ouderschap. 


\section{BAANKENMERKEN}

\subsection{Dienstverband, aanstelling en arbeidsduur}

In dit hoofdstuk wordt ingegaan op de betaalde functies waarin de onderzochte civiel-ingenieurs op het moment van enquêteren werkzaam zijn. Eerst worden de functies getypeerd aan de hand van het soort dienstverband waarin men werkt, de duur van de aanstelling die men heeft en het aantal uren per week dat men werkt. Daarna wordt ingegaan op het beroep dat men uitoefent en het soort organisatie waarin men werkt. Vervolgens komen de voor de functie vereiste opleiding en werkervaring aan bod, waarbij ook de eerste betaalde functie na het afstuderen in de beschouwing wordt betrokken. Tenslotte wordt nagegaan of men binnen de werkorganisatie leiddinggevend werkzaam is en welk inkomen uit arbeid men verwerft.

\section{Dienstverband}

Vrijwel alle $(98 \%)$ civiel-ingenieurs werken in loondienst; $1 \%$ werkt als zelfstandige voor eigen rekening of risico (eigen bedrijf of praktijk) en eveneens $1 \%$ heeft een ander dienstverband. Hierbij doen zich geen significante verschillen tussen de afstudeerrichtingen voor ${ }^{31}$.

\section{Aanstelling}

De meeste $(80 \%)$ van de in loondienst werkende civiel-ingenieurs hebben een vaste aanstelling, dit wil zeggen een aanstelling voor onbepaalde tijd. Van degenen met een tijdelijk begrensde aanstelling $(20 \%)$ werkt $2 \%$ via een uitzendbureau, $4 \%$ in een aanstelling voor maximaal 1 jaar en $14 \%$ in een aanstelling voor langer dan 1 jaar.

Niet alleen bij het dienstverband maar ook ten aanzien van het soort aanstelling zijn verschillen tussen de afstudeerrichtingen niet significant ${ }^{32}$.

\section{Arbeidsduur}

De wekelijkse arbeidsduur is een aspect van de baan dat indicatief is voor de mate van arbeidsparticipatie. Bij de wekelijkse arbeidsduur kan een onderscheid worden gemaakt tussen het aantal feitelijke arbeidsuren en het aantal contractuele arbeidsuren. Contractueel kan een onderscheid worden gemaakt tussen full-time banen (banen waarin men volgens contract meer dan 34 uur per week werkt) en part-time banen (34 uur of minder volgens contract). Indien het aantal feitelijke arbeidsuren groter is dan het aantal contractuele arbeidsuren, is sprake van overwerk.

31. Chi-kwadraat $=11.9$; d.f. $=18 ; p=0.85$.

32. Chi-kwadraat $=20.8$; d.f. $=18 ; p=0.29$. 
Vrijwel iedereen (97\%) van de in loondienst werkende civiel-ingenieurs heeft een full-time baan, dit wil zeggen een baan waarin men volgens contract meer dan 34 uur per week werkt. Hierbij doen zich geen significante verschillen voor tussen mannen en vrouwen ${ }^{33}$, noch tussen de afstudeerrichtingen ${ }^{34}$.

Contractueel werken civiel-ingenieurs gemiddeld 39.5 uur per week (standaardafwijking: 4.3 uur per week); feitelijk werkt men gemiddeld 45.6 uur per week (standaardafwijking: 8.0 uur per week). Per saldo werkt men dus gemiddeld 6.1 uur per week over. Hiervan geeft tabel 5.1 een indicatie. Verschillen tussen mannen en vrouwen ten aanzien van het gemiddeld aantal feitelijke arbeidsuren $^{35}$ en ten aanzien van het gemiddeld aantal contractuele arbeidsuren ${ }^{36}$ zijn overigens niet significant.

Tabel 5.1. Gemiddeld aantal arbeidsuren per week, naar afstudeerrichting

\begin{tabular}{lccc}
\hline & Feitelijk $^{37}$ & Contractuee $^{38}$ & Overwerk $^{{ }^{37}}$ \\
\hline M\&C & 44.0 & 39.6 & 4.4 \\
WB & 47.7 & 41.1 & 6.6 \\
OT & 47.2 & 38.8 & 8.4 \\
UB & 45.3 & 39.2 & 6.1 \\
G\&W & 42.6 & 38.3 & 4.3 \\
VK & 44.8 & 38.7 & 6.1 \\
POO & 47.8 & 39.3 & 8.5 \\
Totaal & 45.6 & 39.5 & 6.1 \\
\hline
\end{tabular}

In tabel 5.1 komt naar voren dat oud-studenten Waterbouwkunde contractueel boven het gemiddeld aantal arbeidsuren van civiel-ingenieurs uitkomen. Wat het feitelijk aantal arbeidsuren betreft, werken oud-studenten Planning, ontwerpen \& organisatie, Waterbouwkunde, Offshoretechnologie langer dan gemiddeld. Per saldo werken oud-studenten Planning, ontwerpen \& organisatie, Offshoretechnologie en Waterbouwkunde langer dan gemiddeld over.

Bij de berekening van de gemiddelde aantallen feitelijk gewerkte uren zijn ook civiel-ingenieurs meegenomen die mogelijk niet overwerken. Wanneer niet iedereen overwerkt, leidt dit uiteraard tot een onderschatting van de omvang van het overwerk door civiel-ingenieurs die wel overwerken. Deze onderschatting is vrij aanzienlijk. Wordt alleen gekeken naar civiel-ingenieurs die overwerken, dit wil zeggen civiel-ingenieurs die feitelijk meer uren werken dan contractueel

33. Chi-kwadraat $=0.9 ;$ d.f. $=1 ; p=0.34$.

34. Chi-kwadraat $=8.4 ;$ d.f. $=6 ; p=0.21$.

35. $F=0.3 ;$ d.f. $=1 ; p=0.61$.

36. $F=0.8 ;$ d.f. $=1 ; p=0.37$.

37. $F=2.8 ;$ d.f. $=6 ; p<0.05$.

38. $F=2.3 ;$ d.f. $=6 ; p<0.05$. 
(72\% van de respondenten), dan wordt gemiddeld 8.6 uur per week overgewerkt.

\subsection{Beroep en werkorganisatie}

In deze paragraaf worden de functies waarin de geënquêteerde civiel-ingenieurs werken, getypeerd aan de hand van het beroep dat men uitoefent en de organisatie waarin men werkt. De werkorganisaties worden achtereenvolgens getypeerd aan de hand van de branche en het soort bedrijf.

Beroep

In tabel 5.2 wordt per afstudeerrichting weergegeven welke de meest uitgeoefende beroepen van de desbetreffende afgestudeerden zijn. Hierbij worden alle beroepen vermeld waarin $5 \%$ of meer van de betaald werkende respondenten werkzaam is. De percentages tellen dus niet noodzakelijkerwijze op tot 100 .

Tabel 5.2. Belangrijkste beroepen, naar afstudeerrichting (in \%)

\begin{tabular}{lrrrrrrr}
\hline & M\&C & WB & OT & UB & G\&W & VK & POO \\
\hline Projectleider & 22 & 33 & 23 & 59 & 16 & 33 & 40 \\
Constructeur & 32 & 17 & 54 & 29 & 16 & & 5 \\
Specialist & 10 & 7 & & & 20 & & 12 \\
Onderzoeker & 19 & 11 & & & 7 & 21 & 5 \\
Adviseur & & 20 & 8 & 6 & 40 & 17 & 12 \\
Manager & 5 & 9 & 15 & 6 & & 8 & 26 \\
Beleidsmedewerker & & & & & & 17 & \\
Ontwerper & & & & & & & \\
\hline
\end{tabular}

Wanneer civiel-ingenieurs zijn afgestudeerd in de richtingen Waterbouwkunde, Utiliteitsbouw, Verkeersbouwkunde \& verkeerskunde of Planning, ontwerpen \& organisatie werken zij het vaakst als projectleider. Met betrekking tot de afstudeerrichtingen Mechanica \& constructies en Offshoretechnologie kan in tabel $\mathbf{5 . 2}$ worden geconstateerd dat het beroep van 'constructeur' het vaakst wordt uitgeoefend. Afgestudeerden van de richting Gezondheidstechniek \& waterbeheersing werken het vaakst als adviseur. Bij de in tabel 5.2 genoemde beroepen dient te worden bedacht dat deze betrekking hebben op oud-studenten in de beginfase van hun carrière.

\section{Branche}

Tabel 5.3 geeft per afstudeerrichting een overzicht van de branchegroepen waarin de onderzochte civiel-ingenieurs terecht zijn gekomen. Omwille van de overzichtelijkheid is een aantal branchegroepen in deze tabel niet verder uitgesplitst, te weten advies-/ingenieursbureaus, andere bedrijven dan aannemers-/bouw-/baggerbedrijven en overheidsinstellingen. In tabel 5.4, 
die in bijlage 1 is opgenomen, worden deze branchegroepen wel verder onderverdeeld.

Tabel 5.3. Branchegroepen, naar afstudeerrichting (in \%)

\begin{tabular}{|c|c|c|c|c|c|c|c|}
\hline & $M \& C$ & WB & OT & UB & G\&W & VK & POO \\
\hline $\begin{array}{l}\text { Advies-/ingenieursbureau } \\
\text { Aannemers-/bouw-/ }\end{array}$ & 58 & 35 & 54 & 59 & 58 & 38 & 28 \\
\hline baggerbedrijf & 20 & 30 & 23 & 29 & 2 & 13 & 44 \\
\hline Overige bedrijven & 3 & 6 & 23 & 12 & 4 & 4 & 16 \\
\hline Overheden & 3 & 20 & & & 20 & 25 & 7 \\
\hline Universiteit & 3 & 4 & & & 7 & 17 & 5 \\
\hline $\begin{array}{l}\text { Overige onderzoeks- } \\
\text { instellingen }\end{array}$ & 12 & 6 & & & 9 & 4 & \\
\hline Totaal $n(=100 \%)$ & 59 & 54 & 13 & 17 & 45 & 24 & 43 \\
\hline
\end{tabular}

In tabel 5.3 komt naar voren dat de meerderheid van de oud-studenten Utiliteitsbouw, Mechanica \& constructies, Gezondheidstechniek \& waterbeheersing en Offshoretechnologie werkzaam zijn in advies-/ingenieursbureaus. Om welk soort bureaus het hierbij gaat, staat vermeld in tabel 5.4 , die in bijlage 1 is opgenomen. Oud-studenten Planning, ontwerpen \& organisatie komen het vaakst terecht in aannemers-/bouw-/baggerbedrijven. Afgestudeerde waterbouwkundigen werken ongeveer even vaak in advies-/ingenieursbureaus als in aannemers-/bouw-/baggerbedrijven.

Tabel 5.4 (bijlage 1) geeft per afstudeerrichting een overzicht van de belangrijkste branches waarin de onderzochte civiel-ingenieurs werkzaam zijn. In tegenstelling tot de vorige tabel zijn de advies-/ingenieursbureaus, andere bedrijven dan aannemers-/bouw-/baggerbedrijven en overheidsinstellingen in deze tabel wel nader uitgesplitst. Als criterium geldt dat tenminste $5 \%$ van de respondenten in de desbetreffende branche werkzaam zijn. Evenals in de tabel met de belangrijkste beroepen het geval was (tabel 5.2), tellen de percentages dus niet noodzakelijkerwijze op tot 100 .

\section{Soort werkorganisatie}

De grootste groep respondenten (51\%) werkt bij Nederlandse bedrijven; $18 \%$ bij een internationaal bedrijf met de hoofdzetel in Nederland, $15 \%$ bij de Nederlandse overheid, $4 \%$ bij een technische universiteit en 7\% bij een onderzoeksinstelling zoals TNO of het Waterbouwkundig Laboratorium. Slechts $1 \%$ werkt bij een buitenlands bedrijf. De resterende $4 \%$ werkt bij een ander soort organisatie dan de bovengenoemden. De afstudeerrichtingen verschillen significant met betrekking tot het soort werkorganisaties waarin de oud-studenten terecht zijn gekomen. Hiervan geeft tabel 5.5 een beeld. 
Tabel 5.5. Soort werkorganisatie (in \%)

\begin{tabular}{|c|c|c|c|c|c|c|c|c|}
\hline & $M \& C$ & WB & OT & UB & G\&W & VK & POO & Tot \\
\hline Onderzoeksinstelling & 17 & 6 & & & 9 & 4 & & 7 \\
\hline Nederlandse overheid & 7 & 23 & & 12 & 25 & 25 & 7 & 15 \\
\hline Nederlands bedrijf & 63 & 36 & 62 & 47 & 43 & 46 & 65 & 51 \\
\hline $\begin{array}{l}\text { Internationaal bedrijf } \\
\text { (hoofdzetel Nederland) }\end{array}$ & 10 & 30 & 23 & 35 & 9 & 8 & 21 & 18 \\
\hline Buitenlands bedrijf & & & 8 & & 2 & & 2 & 1 \\
\hline TU & 2 & 6 & & & 2 & 17 & 5 & 4 \\
\hline Overig & 2 & & 8 & 6 & 9 & & & 3 \\
\hline Totaal $n(=100 \%)$ & 59 & 53 & 13 & 17 & 44 & 24 & 43 & 253 \\
\hline
\end{tabular}

Oud-studenten Mechanica \& constructies werken vaker dan gemiddeld bij een onderzoeksinstelling of een Nederlands bedrijf; oud-studenten Verkeersbouwkunde \& verkeerskunde bij de Nederlandse overheid of een technische universiteit. Afgestudeerden Waterbouwkunde en Utiliteitsbouw komen vaker dan gemiddeld terecht in internationale bedrijven met hoofdzetel in Nederland. Oud-studenten Gezondheidstechniek \& waterbeheersing werken vaker dan gemiddeld in Nederlandse overheidsdienst. Afgestudeerden Offshoretechnologie en Planning, ontwerpen \& organisatie zijn vaker dan gemiddeld bij Nederlandse bedrijven werkzaam. Daarnaast werken oud-studenten Offshoretechnologie relatief vaak bij buitenlandse bedrijven. Niemand van de bevraagde oud-studenten Offshoretechnologie werkt daarentegen in overheidsdienst, bij een technische universiteit of bij een andere onderzoeksinstelling.

\subsection{Functievereisten}

Het centrale thema van deze paragraaf betreft de eisen die werkgevers stellen aan startfuncties van civiel-ingenieurs. Bij de respondenten die al eens van functie zijn veranderd $(67 \%)$, is tevens gevraagd naar de eisen die aan hun laatste functie worden gesteld. In deze paragraaf wordt achtereenvolgens ingegaan op het niveau en de richting van de opleiding die voor de functie was vereist en op de vraag of werkervaring voor de functie werd vereist.

\section{Vereist opleidingsniveau}

In tabel 5.6 komt naar voren dat de meeste $(81 \%)$ civiel-ingenieurs hun loopbaan starten in functies op universitair niveau en na verandering van functie hun loopbaan in universitaire functies voortzetten (87\%). Oud-studenten Utiliteitsbouw en Planning, ontwerpen \& organisatie starten vaker dan gemiddeld in HBO-functies, waarbij oud-studenten Utiliteitsbouw ook vaker dan gemiddeld hun loopbaan in HBO-functies voortzetten. 
$-28-$

Tabel 5.6. Minimaal vereist opleidingsniveau voor startfuncties en latere functies (in \%)

\begin{tabular}{lllllllllllll}
\hline M\&C & WB & OT & UB & G\&W & VK & POO & Tot \\
\hline
\end{tabular}

\section{A. Startfuncties}

\begin{tabular}{|c|c|c|c|c|c|c|c|c|}
\hline $\begin{array}{l}\text { VWO-, MBO-niveau } \\
\text { HBO-niveau } \\
\text { WO-niveau }\end{array}$ & $\begin{array}{r}2 \\
15 \\
83\end{array}$ & $\begin{array}{r}2 \\
4 \\
94\end{array}$ & $\begin{array}{r}8 \\
8 \\
85\end{array}$ & $\begin{array}{r}6 \\
35 \\
59\end{array}$ & $\begin{array}{r}11 \\
2 \\
87\end{array}$ & $\begin{array}{r}4 \\
4 \\
92\end{array}$ & $\begin{array}{l}14 \\
26 \\
61\end{array}$ & $\begin{array}{r}6 \\
12 \\
81\end{array}$ \\
\hline Totaal $n(=100 \%)$ & 59 & 52 & 13 & 17 & 45 & 24 & 43 & 253 \\
\hline \multicolumn{9}{|c|}{$\mathrm{Chi}^{2}=36.6 ;$ d.f. $=12 ; \mathrm{P}<0.01$} \\
\hline & $M \& C$ & WB & OT & UB & G\&W & VK & POO & Tot \\
\hline
\end{tabular}

B. Latere functies

\begin{tabular}{lrrrrrrrr} 
VWO-, MBO-niveau & & & & & 4 & 7 & & 1 \\
$\begin{array}{l}\text { HBO-niveau } \\
\text { WO-niveau }\end{array}$ & 19 & 7 & & 39 & 4 & & 13 & 12 \\
& 81 & 93 & 100 & 62 & 93 & 93 & 88 & 87 \\
Totaal n $(=100 \%)$ & 31 & 27 & 11 & 13 & 28 & 14 & 32 & 156 \\
\hline Chi ${ }^{2}=22.6 ; d . f=12 ; P<0.05$ & & & &
\end{tabular}

$\mathrm{Chi}^{2}=22.6 ;$ d.f $=12 ; \mathrm{P}<0.05$

In de enquête is gevraagd naar het niveau van de opleiding dat voor de uitoefening van de functie minimaal werd vereist. Wanneer dit onder universitair niveau ligt, wijst dat op een potentiële onderbenutting van capaciteiten bij de uitoefening van de functie. Of dit als problematisch moet worden beschouwd, hangt vooral af van de omvang van het percentage civiel-ingenieurs die een functie uitoefenen beneden hun opleidingsniveau. Met betrekking tot de eerste functie na het afstuderen mag niet worden vergeten dat het hier om startfuncties gaat, waarbij mogelijk ook binnen de organisatie nog doorgroeimogelijkheden zijn naar functies op universitair niveau. Een hoog onderbenuttingspercentage wijst echter duidelijk in de richting van een slechte marktpositie voor de betreffende afstudeerrichting (Van der Velden \& Willems, 1992).

\section{Vereiste opleidingsrichting}

Aan de respondenten is ook de vraag voorgelegd welke opleidingsrichting voor de huidige functie werd vereist. Hiervan geeft tabel 5.7 een beeld.

De meeste civiel-ingenieurs komen terecht in functies waarvoor de studierichting Civiele Techniek specifiek is vereist. Minder frequent zijn functies die ook kunnen worden vervuld door afgestudeerden van aanverwante opleidingsrichtingen. Circa eentiende heeft functies waarvoor geen specifieke opleidingsrichting of een geheel andere richting dan Civiele Techniek is vereist. Met betrekking tot de vereiste opleidingsrichting zijn er over het geheel genomen slechts kleine 
verschillen tussen de eerste functies na het afstuderen en latere functies.

Oud-studenten Utiliteitsbouw en Planning, ontwerpen \& organisatie starten hun loopbaan vaker dan gemiddeld in minder specialistische functies, dit wil zeggen functies die ook kunnen worden vervuld door afgestudeerden van aanverwante opleidingsrichtingen, waarbij oud-studenten Utiliteitsbouw ook vaker dan gemiddeld hun loopbaan in dergelijke functies voortzetten. Hoewel oud-studenten Offshoretechnologie en Mechanica \& constructies hun loopbaan niet vaker dan gemiddeld in dergelijke minder specialistische functies starten, zetten zij wel, evenals oudstudenten Utiliteitsbouw, hun loopbaan relatief vaak in dergelijke functies voort. Niet alleen starten oud-studenten Verkeersbouwkunde \& verkeerskunde en Gezondheidstechniek \& waterbeheersing hun loopbaan vaker dan gemiddeld in functies die qua vereiste opleidingsrichting exclusief voor hen zijn weggelegd, zij zetten ook vaker dan gemiddeld hun loopbaan in dergelijke gespecialiseerde functies voort.

Tabel 5.7. Vereiste opleidingsrichting voor startfuncties en latere functies (in \%)

$\begin{array}{lllllll}\text { M\&C } & \text { WB } & \text { OT } & \text { UB } & \text { G\&W } & \text { VK } & \text { POO }\end{array}$

A. Startfuncties

Niet $\mathrm{CT}^{*}$

CT of aanverwante opleiding

Uitsluitend $\mathrm{CT}$

Uitsluitend gevolgde richting

binnen CT

Andere richting binnen $\mathrm{CT}$

Totaal n (=100\%)

* geen specifieke opleidingsrichting vereist of een geheel andere opleidingsrichting dan Civiele Techniek (CT) vereist

$\mathrm{Chi}^{2}=73.5 ;$ d.f $=24 ; \mathrm{P}<0.01$

M\&C WB OT UB G\&W VK POO Tot

\section{B. Latere functies}

Niet $C T^{*}$

$\mathrm{CT}$ of aanverwante opleiding

Uitsluitend CT

$\begin{array}{rr}2 & 6 \\ 36 & 23 \\ 19 & 25 \\ 43 & 44\end{array}$

8
39
15
39

72

11

$22 \quad 58$

6

58

\section{3}

18

4

2

$9 \quad 13$

4

4

23

44

19

14

31

16

43

53

$\begin{array}{rr}8 & \\ 54 & 29 \\ & 11 \\ 39 & 61\end{array}$

$\begin{array}{rrr}14 & 34 & 12 \\ & 19 & 26 \\ 7 & 38 & 19 \\ 71 & 3 & 39\end{array}$

$\begin{array}{rrr}7 & 7 & \\ 36 & 7 & 64 \\ 10 & 33 & 18 \\ 45 & 41 & 18\end{array}$

binnen $\mathrm{CT}$

Andere richting binnen $\mathrm{CT}$

311

Totaal $n(=100)$

31

27

11

13

28

71

3

39

* geen specifieke opleidingsrichting vereist of een geheel andere opleidingsrichting dan Civiele Techniek (CT) vereist

$\mathrm{Chi}^{2}=78,5 ;$ d.f. $=24 ; \mathrm{P}<0.01$ 


\section{Vereiste werkervaring}

De grootste verschillen tussen startfuncties en latere functies doen zich voor met betrekking tot de vraag of werkervaring werd vereist. Vormt werkervaring bij nog 'slechts' $11 \%$ van de startfuncties een vereiste, in $62 \%$ van de latere functies wordt werkervaring vereist. Dit betekent dat functieverandering in de meeste gevallen de overgang naar een zwaardere functie inhoudt.

Er zijn geen significante verschillen tussen de afstudeerrichtingen met betrekking tot de mate waarin afgestudeerden worden geconfronteerd met de eis van werkervaring, noch in startfuncties $^{39}$, noch in latere functies ${ }^{40}$.

\subsection{Leidinggeven en inkomen}

In deze paragraaf wordt eerst nagegaan of men een leidinggevende functie uitoefent. Vervolgens komt de hoogte van het genoten inkomen aan bod.

\section{Leidinggeven}

Tabel 5.8 geeft een beeld van de mate waarin civiel-ingenieurs in leidinggevende functies werkzaam zijn. Hierin komt naar voren dat bijna de helft van deze populatie van pas afgestudeerden leidinggevend werkzaam is, waarbij men doorgaans aan 1-4 medewerkers leiding geeft.

Er zijn geen significante verschillen tussen de afstudeerrichtingen met betrekking tot de mate waarin afgestudeerden in leidingggevende functies terecht komen ${ }^{41}$.

Tabel 5.8. Mate van leidinggeven in huidige functie (in \%)

$\begin{array}{lr}\text { geen leidinggevende functie } & 53 \\ \text { leiding aan 1-4 medewerkers } & 34 \\ \text { leiding aan 5-9 medewerkers } & 6 \\ \text { leiding aan 10-19 medewerkers } & 4 \\ \text { leiding aan }>19 \text { medewerkers } & 3 \\ & \\ \text { Totaal } n(=100 \%) & 253\end{array}$

Inkomen uit arbeid

Aan degenen met een betaalde baan is gevraagd naar de hoogte van het totale bruto maandinkomen (exclusief vakantiegeld of inkomen uit nevenfuncties). Men is gevraagd om een

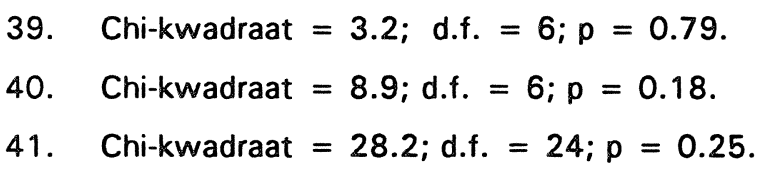


eventuele $13 \mathrm{e}$ maand of jaargratificatie voor $1 / 12$ deel mee te rekenen. Daarnaast is gevraagd welk deel van het totale bruto maandinkomen bestaat uit toeslagen voor overwerk, onregelmatig werk, ploegendienst e.d.

Tabel 5.9 geeft per afstudeerrichting een beeld van het gemiddeld bruto maandinkomen, inclusief en exclusief toeslagen. In deze tabel is tevens het gemiddeld bruto uurloon opgenomen. Dit is berekend door het totale bruto maandinkomen te verminderen met de toeslagen voor overwerk e.d., en het verschil (het standaardloon) te delen door het aantal uren dat men contractueel per maand werkt. Onder de respondenten bevonden zich 2 oud-studenten met een inkomen dat hoger is dan FI. 10.000,- bruto per maand. Om een vertekening als gevolg van deze extreem hoge inkomens tegen te gaan, zijn de inkomens van deze 2 respondenten niet meegenomen in de berekening van het gemiddeld bruto maandinkomen en het gemiddeld bruto uurloon.

Tabel 5.9. Gemiddeld bruto maandinkomen en gemiddeld bruto uurloon, in Nederlandse guldens (de getallen tussen haakjes geven de standaardafwijking weer)

\begin{tabular}{llrlrl}
\hline & \multicolumn{2}{l}{$\begin{array}{l}\text { Inkomen } \\
\text { (incl. toeslagen) }\end{array}$} & \multicolumn{2}{l}{$\begin{array}{l}\text { Inkomen } \\
\text { (excl. toeslagen) }\end{array}$} & Uurloon \\
& & & & & \\
\hline M\&C & 4440 & $(875)$ & 4343 & $(661)$ & 25 \\
WB & 4738 & $(1333)$ & 4541 & $(1043)$ & 26 \\
OT & 5147 & $(653)$ & 4867 & $(640)$ & 28 \\
UB & 4520 & $(706)$ & 4514 & 703 & 27 \\
G\&W & 4421 & $(1156)$ & 4326 & $(1227)$ & 26 \\
VK & 4167 & $(610)$ & 4150 & $(639)$ & 25 \\
POO & 4813 & $(1144)$ & 4784 & $(1110)$ & 27 \\
Totaal & 4572 & $(1065)$ & 4464 & $(961)$ & 26 \\
\hline
\end{tabular}

Zowel met als zonder toeslagen verwerven oud-studenten Offshoretechnologie het hoogste bruto maandinkomen, gevolgd door oud-studenten Planning, ontwerpen \& organisatie en oudstudenten Waterbouwkunde. Ook wanneer wordt gecorrigeerd voor overwerk e.d. verdienen oud-studenten Offshoretechnologie het hoogste inkomen (uurloon), echter nu gevolgd door oudstudenten Planning, ontwerpen \& organisatie en oud-studenten Utiliteitsbouw. In tabel 5.9 komt verder naar voren dat verschillen in bruto maandinkomen het grootst zijn onder oud-studenten Waterbouwkunde (exclusief toeslagen zijn de inkomensverschillen het grootst onder oudstudenten Gezondheidstechniek \& waterbeheersing).

42. $F=2.0 ;$ d.f. $=6 ; p=0.07$.

43. $F=1.6 ;$ d.f. $=6 ; p=0.15$.

44. $F=1.2 ;$ d.f. $=6 ; p=0.32$. 


\subsection{Samenvatting}

De meeste geënquêteerde civiel-ingenieurs werken in loondienst $(98 \%)$, hebben een vaste aanstelling $(80 \%)$ en oefenen full-time functies uit $(97 \%)$. Contractueel werkt men gemiddeld 39.5 uur per week; feitelijk werkt men gemiddeld 45.6 uur per week. Per saldo werkt men dus gemiddeld 6.1 uur per week over.

Bijna de helft van de betaald werkende respondenten heeft een leidinggevende functie, waarin men doorgaans aan 1-4 medewerkers leiding geeft. Oud-studenten Offshoretechnologie verdienen het hoogste inkomen, gemeten volgens het uurloon, gevolgd door oud-studenten Planning, ontwerpen \& organisatie en oud-studenten Utiliteitsbouw. Oud-studenten Waterbouwkunde, Utiliteitsbouw, Verkeersbouwkunde \& verkeerskunde en Planning, ontwerpen \& organisatie werken het vaakst als projectleider, oud-studenten Mechanica \& constructies en Offshoretechnologie als constructeur en oud-studenten Gezondheidstechniek \& waterbeheersing als adviseur. Wat de branche betreft, komen oud-studenten Utiliteitsbouw, Mechanica \& constructies, Gezondheidstechniek \& waterbeheersing, Offshoretechnologie en Verkeersbouwkunde \& verkeerskunde het vaakst terecht in advies-/ingenieursbureaus. Oud-studenten Planning, ontwerpen \& organisatie zijn het vaakst werkzaam in aannemers-/bouw-/baggerbedrijven. Afgestudeerde waterbouwkundigen werken ongeveer even vaak in advies-/ingenieursbureaus als in aannemers-/bouw-/baggerbedrijven. Overigens werkt de grootste groep respondenten $(51 \%)$ in het Nederlandse bedrijfsleven.

De meeste civiel-ingenieurs starten hun loopbaan in functies waarvoor een universitaire opleiding is vereist $(81 \%)$, en zetten na verandering van functie hun loopbaan in universitaire functies voort $(87 \%)$.

Ook starten de meeste civiel-ingenieurs hun loopbaan in functies waarvoor de studierichting Civiele Techniek specifiek is vereist $(61 \%)$, en zetten na functieverandering hun loopbaan in dergelijke qua opleidingsrichting aansluitende functies voort $(62 \%)$. Functieverandering impliceert in de meeste gevallen de overgang van een functie waarvoor werkervaring niet is vereist naar een functie waarvoor werkervaring wel vereist is. 


\section{OORDEEL OVER DE AANSLUITING TUSSEN DE GEVOLGDE STUDIE EN DE HUIDIGE FUNCTIE}

\subsection{Inleiding}

Centraal in dit hoofdstuk staat de aansluiting tussen de tijdens de studie verworven kennis en vaardigheden en de eisen die hieraan in de huidige functie worden gesteld. Nagegaan zal worden in welke mate zich zogenaamde 'afstemmingsproblemen' voordoen in de beginfase van de beroepsloopbaan van civiel-ingenieurs.

Van (vak-)inhoudelijke discrepanties tussen de studie en de functie is sprake wanneer er kwalificaties in het onderwijs worden bijgebracht die niet passen bij de kwalificaties die worden vereist vanuit het werkveld. In de enquête zijn deze discrepanties opgesplitst in kennisgebieden en vaardigheden. De lijst van kennisgebieden is opgesteld door de Faculteit der Civiele Techniek. De lijst van vaardigheden is grotendeels gebaseerd op ervaringen die zijn opgedaan met de zogenaamde 'HBO-Monitor' en is afkomstig van het ROA.

Voor alle afstudeerrichtingen is dezelfde groep van aspecten gehanteerd. De aspecten zijn zo geformuleerd dat zij voor mensen uit de verschillende werkvelden toepasbaar zijn. Wel is het van belang om op te merken dat hier uitsluitend het oordeel van de afgestudeerden aan bod komt. Dit hoeft uiteraard niet overeen te stemmen met het oordeel vanuit het werkveld.

Voor het achterhalen van eventuele afstemmingsproblemen is aan de respondenten die betaald werk hebben (gehad) een lijst voorgelegd met 29 aspecten op het gebied van kennis en vaardigheden die voor een goede uitoefening van hun huidige (of laatste) functie van belang zijn (geweest). Bij elk aspect is gevraagd om aan te geven in hoeverre dit van belang is voor de uitoefening van de functie, of er meer of minder aandacht aan dit aspect tijdens de studie besteed moet worden, en of de afgestudeerde behoefte heeft (gehad) aan bijscholing met betrekking tot dit aspect.

Het belang van de kennisgebieden en vaardigheden wordt in paragraaf 6.2 besproken. De mate van aandacht komt in paragraaf 6.3 aan bod en de behoefte aan bijscholing in paragraaf 6.4 . In paragraaf 6.5 worden de bevindingen van dit hoofdstuk samengevat.

\subsection{Belang van kennisgebieden en vaardigheden}

Voor zowel de kennisgebieden als voor de vaardigheden is gebruik gemaakt van een vier-punts schaal waarop de afgestudeerden het belang kunnen aangeven dat zij aan een bepaald aspect toekennen. Deze schaal bevat de volgende categorieën:

- zeer belangrijk;

- tamelijk belangrijk;

- vrij onbelangrijk; 
- onbelangrijk.

Vanwege de vraagstelling: 'het belang van het aspect voor de huidige functie', worden de resultaten niet per afstudeerrichting, maar per beroep weergegeven. Om de uitkomsten overzichtelijk te kunnen weergeven, zijn de functies geaggregeerd tot de volgende 6 beroepen (tussen haakjes staat het procentuele aandeel van het beroep in het totaal van het aantal betaald werkende oud-studenten):

- constructeur $(22 \%)$;

- adviseur (18\%);

- specialist (11\%);

- projectleider $(30 \%)$;

- manager $(9 \%)$;

- onderzoeker (11\%).

\section{Kennisgebieden}

Met betrekking tot de volgende twee kennisgebieden vindt meer dan de helft van de beroepsbeoefenaren dat het desbetreffende kennisgebied belangrijk is voor een goede beroepsuitoefening (tabel 1, bijlage 1):

- grondmechanica/geotechniek (63\% belangrijk);

- civieltechnische informatica (58\% belangrijk).

Verbijzondering naar afstudeerrichting van de mate van belangrijkheid van deze twee kennisgebieden, laat zien dat Planning, ontwerpen \& organisatie de enige studierichting is waarbij meer dan de helft $(61 \%)$ van de oud-studenten het kennisgebied grondmechanica/geotechniek onbelangrijk acht voor de beroepsuitoefening ${ }^{45}$. Met betrekking tot het belang voor de beroepsuitoefening van het kennisgebied civieltechnische informatica zijn er geen significante verschillen tussen de afstudeerrichtingen ${ }^{46}$. De kennisgebieden verkeerskunde, houtconstructies, offshoretechnologie, verkeersbouwkunde, utiliteitsbouw/bouwfysica en hydrologie/waterbeheersing worden door de bank genomen minder vaak belangrijk geacht voor de beroepsuitoefening.

Wat de verschillen tussen de beroepen betreft, komt in tabel 1 (bijlage 1) naar voren dat algemene en toegepaste mechanica, beton- en staalconstructies en grondmechanica/geotechniek vooral belangrijke kennisgebieden zijn voor constructeurs. Algemene en toegepaste mechanica is ook voor met name onderzoekers een belangrijk kennisgebied, evenals civieltechnische informatica en grondmechanica. Civiel-ingenieurs die als specialist werken vinden vloeistofen grondmechanica relatief belangrijk. Voor adviseurs belangrijke kennisgebieden zijn grondmechanica/geotechniek, hydrologie/waterbeheersing, gezondheidstechniek/milieutechnologie en civieltechnische informatieca. Civiele bedrijfskunde en civieltechnische informatieca zijn

45. Chi-kwadraat $=19.8$; d.f. $=6 ; p<0.01$.

46. Chi-kwadraat $=8.8 ;$ d.f. $=6 ; p=0.18$. 
belangrijke kennisgebieden voor civiel-ingenieurs die werkzaam zijn als manager of projectleider. Voor het laatste beroep zijn bovendien ook materiaalkunde en grondmechanica belangrijk.

\section{Vaardigheden}

Met betrekking tot de volgende vijf vaardigheden is meer dan $90 \%$ van de beroepsbeoefenaren van mening dat deze belangrijk zijn voor een goede beroepsuitoefening (tabel 1, bijlage 1):

- zelfstandigheid, initiatief;

- aanpassings- en improvisatievermogen;

- samenwerken, teamwork;

- plannen, coördineren, organiseren;

- trouble shooting.

Commerciële kennis en vaardigheden alsmede voorlichten, adviseren, verzorgen van public relations worden door de bank genomen minder vaak van belang geacht voor de beroepsuitoefening.

Hierbij manifesteert zich een aantal verschillen tussen de beroepen. Zo zijn leiding geven, contacten leggen en commerciële kennis relatief belangrijke vaardigheden voor civiel-ingenieurs, werkzaam als projectleider of manager. Voor managers komt hier nog voorlichten, adviseren, verzorgen van public relations bij. De laatsgenoemde vaardigheden zijn tevens voor met name adviseurs van belang. Een aantal vaardigheden blijken voor onderzoekers minder belangrijk te zijn, namelijk trouble shooting, stressbestendigheid, commerciële kennis en teamwork.

\subsection{Oordeel over de aansluiting}

Nadat in paragraaf 6.2 het belang van de verschillende kennisgebeiden en vaardigheden voor de uitoefening van de huidige functie is aangegeven, wordt in deze paragraaf nagegaan of deze aspecten tijdens de studie voldoende aandacht hebben gekregen. De resultaten worden daarom per afstudeerrichting gepresenteerd.

De afgestudeerden konden in de vragenlijst op een drie-puntsschaal aangeven of er tijdens de studie meer, evenveel, of minder aandacht aan de diverse aspecten moet worden besteed. Om de hoeveelheid te presenteren informatie te beperken, zijn de antwoorden omgezet naar een intervalschaal: 'meer aandacht' krijgt de waarde +1 , 'evenveel aandacht' krijgt de waarde 0 en aan 'minder aandacht' wordt de waarde -1 toegekend.

Het gemiddelde kan dus variëren van ' -1 ' (indien alle afgestudeerden vinden dat aan het aspect minder aandacht moet worden besteed) tot ' +1 ' (indien alle afgestudeerden van mening zijn dat aan het aspect meer aandacht moet worden besteed). De standaardafwijking geeft de mate van spreiding van de antwoorden weer (' $O$ ' indien alle afgestudeerden dezelfde mening hebben en in dit geval 1 indien de meningen lijnrecht tegenover elkaar staan).

In tabel 2 van bijlage 1 staat per aspect de gemiddelde score en de standaardafwijking vermeld. 


\section{Kennisgebieden}

Civiel-ingenieurs zijn door de bank genomen van mening dat de volgende kennisgebieden tijdens de opleiding meer aandacht zouden moeten krijgen (tabel 2, bijlage 1):

- civieltechnische informatica;

- civiele bedrijfskunde;

- grondmechanica/geotechniek;

- gezondheidstechniek/milieutechnologie.

Aan de volgende kennisgebieden zou naar de mening van de geënquêteerde civiel-ingenieurs daarentegen best wat minder aandacht kunnen worden besteed:

- houtconstructies;

- utiliteitsbouw/bouwfysica;

- verkeerskunde.

Hierbij dient te worden opgemerkt dat zich bij de meeste kennisgebieden significante verschillen voordoen tussen de afstudeerrichtingen met betrekking tot de aandacht die men aan het desbetreffende kennisgebied besteed zou willen zien (zie tabel 2 in bijlage 1). Zo zouden oudstudenten Utiliteitsbouw en Planning, ontwerpen \& organisatie evenveel of meer aandacht besteden aan houtconstructies, en oud-studenten Verkeersbouwkunde \& verkeerskunde aan het kennisgebied verkeerskunde. Aan utiliteitsbouw/bouwfysica zouden oud-studenten Mechanica \& constructies, Utiliteitsbouw en Planning, ontwerpen \& organisatie evenveel of meer aandacht besteed willen zien.

\section{Vaardigheden}

Geen enkel vaardigheidsaspect zou volgens de respondenten tijdens de opleiding minder aandacht moeten krijgen. In tabel 2 (bijlage 1) komt naar voren dat vooral de volgende vaardigheidsaspecten meer aandacht zouden moeten krijgen:

- leiding geven;

- kennis overdragen;

- plannen, coördineren en organiseren;

- contacten leggen en onderhouden met cliënten, opdrachtgevers e.d.

Significante verschillen tussen afstudeerrichtingen doen zich alleen voor met betrekking tot het aspect voorlichten, adviseren, verzorgen van public relations. Oud-studenten Utiliteitsbouw en Planning, ontwerpen \& organisatie vinden vaker dan gemiddeld dat aan dit aspect tijdens de opleiding meer aandacht moet worden besteed.

\subsection{Behoefte aan bijscholing}

In deze paragraaf wordt nagegaan in hoeverre afgestudeerden bijscholing behoeven op én of meer kennisgebieden of vaardigheden. In tabel 3 van bijlage 1 staat het percentage werkenden dat behoefte heeft (gehad) aan bijscholing met betrekking tot de desbetreffende aspecten. 


\section{Kennisgebieden}

De grootste behoefte aan bijscholing in kennisgebieden doet zich voor met betrekking tot civiele bedrijfskunde, grondmechanica/geotechniek en civieltechnische informatica. Tabel 3 in bijlage 1 geeft hiervan een beeld. Significante verschillen in bijscholingsbehoefte tussen de afstudeerrichtingen doen zich voor met betrekking tot de volgende kennisgebieden:

- gezondheidstechniek/milieutechnologie;

- civieltechnische informatica;

- hydrologie/waterbeheersing;

- algemene en toegepaste mechanica;

- offshoretechnologie.

Oud-studenten Mechanica \& constructies hebben meer dan gemiddeld behoefte aan bijscholing op het gebied van algemene en toegepaste mechanica, oud-studenten Waterbouwkunde op het gebied van offshoretechnologie, oud-studenten Gezondheidstechniek \& waterbeheersing op het gebied van hydrologie/waterbeheersing en gezondheidstechniek/milieutechnologie, en oudstudenten Planning, ontwerpen en organisatie op het gebied van civieltechnische informatica.

\section{Vaardigheden}

Wat de vaardigheden betreft, komt in tabel 3 (bijlage 1) naar voren dat tenminste een derde van de geënquêteerde civiel-ingenieurs behoefte heeft aan bijscholing op het gebied van:

- leiding geven;

- contacten leggen en onderhouden met cliënten, opdrachtgevers e.d.;

- commerciële kennis en vaardigheden;

- kennis overdragen.

De verschillen in bijscholingsbehoefte op het gebied van vaardigheden tussen de afstudeerrichtingen zijn niet significant.

Dit laat uiteraard onverlet dat er tussen de beroepen wel significante verschillen in de bijscholingsbehoefte kunnen bestaan. Derhalve is ook nagegaan of de onderscheiden beroepsgroepen verschillen in hun behoefte aan bijscholing. Gebleken is dat managers significant meer behoefte hebben aan bijscholing op het gebied van:

- contacten leggen en onderhouden met cliënten, opdrachtgevers e.d.,

- voorlichten, adviseren, verzorgen van public relations, en

- commerciële kennis en vaardigheden

dan civiel-ingenieurs die een ander beroep uitoefenen. Verder is gebleken dat adviseurs relatief vaak behoefte hebben aan bijscholing met betrekking tot contacten leggen en onderhouden met cliënten, opdrachtgevers e.d.

\subsection{Samenvatting}

Aan de respondenten zijn 29 kennisgebieden en vaardigheidsaspecten voorgelegd, die bij de functie-uitoefening van belang kunnen zijn. De respondenten is gevraagd om aan te geven in 
hoeverre deze kennisgebieden en vaardigheden van belang zijn voor de uitoefening van hun beroep, in hoeverre tijdens de opleiding voldoende aandacht aan deze kennisgebieden en vaardigheden is besteed, en of zij behoefte hebben (gehad) aan bijscholing met betrekking tot de kennisgebieden en vaardigheden.

\section{Kennisgebieden}

Tenminste de helft van de respondenten vindt dat de kennisgebieden grondmechanica/geotechniek, civieltechnische informatica en civiele bedrijfskunde belangrijk zijn voor een goede beroepsuitoefening. Deze kennisgebieden zouden volgens de meeste oud-studenten meer aandacht moeten krijgen in de opleiding. Meer dan een kwart van de respondenten heeft dan ook behoefte aan bijscholing op deze kennisgebieden.

Hoewel meer dan de helft van de respondenten vindt dat algemene en toegepaste mechanica een voor de beroepsuitoefening belangrijk kennisgebied is, bestaat er slechts een beperkte behoefte aan bijscholing op dit gebied. Men vindt dan ook dat dit kennisgebied tijdens de opleiding voldoende aandacht heeft gekregen.

Met betrekking tot het kennisgebied gezondheidstechniek/milieutechnologie bestaat een vrij grote bijscholingsbehoefte. Men is dan ook van mening dat dit kennisgebied in de opleiding meer aandacht zou moeten krijgen. Dit laat onverlet dat 'slechts' een derde van de respondenten gezondheidstechniek/milieutechnologie belangrijk vindt voor de beroepsuitoefening.

Volgens oud-studenten van de meeste afstudeerrichtingen zou aan de kennisgebieden houtconstructies, utiliteitsbouw/bouwfysica en verkeerskunde in de opleiding minder aandacht kunnen worden besteed. Doorgaans vindt men deze kennisgebieden niet zo belangrijk voor de beroepsuitoefening. De bijscholingsbehoefte in deze kennisgebieden is dan ook door de bank genomen niet erg groot. Deze bevinding geldt overigens niet steeds voor alle afstudeerrichtingen. Zo vinden de meeste oud-studenten Verkeersbouwkunde \& verkeerskunde dat het kennisgebied verkeerskunde wel degelijk belangrijk is voor de beroepsuitoefening (circa een vijfde van hen heeft dan ook behoefte aan bijscholing op dit gebied). Oud-studenten Utiliteitsbouw vinden de kennisgebieden utiliteitsbouw/bouwfysica en houtconstructies wel van belang voor de beroepsuitoefening. Aan houtconstructies zouden oud-studenten Utiliteitsbouw zelfs als enigen meer aandacht willen besteden. De behoefte aan bijscholing op het kennisgebied houtconstructies is met name voor de afstudeerrichtingen Mechanica \& constructies en Planning, ontwerpen \& organisatie, met respectievelijk $15 \%$ en $14 \%$, hoger dan voor andere afstudeerrichtingen. Met betrekking tot de behoefte aan bijscholing op het kennisgebied utiliteitsbouw scoren de oudstudenten Utiliteitsbouw met $24 \%$ duidelijk het hoogst.

Over het geheel genomen vinden oud-studenten dat aan de kennisgebieden betonconstructies, staalconstructies, waterbouwkundige constructies, algemene waterbouwkunde, vloeistofmechanica, offshoretechnologie, hydrologie/waterbeheersing, verkeersbouwkunde en infrastructuur/planologie in de opleiding voldoende aandacht wordt besteed. Ook scoren deze kennisge- 
bieden qua belang voor de beroepsuitoefening en qua bijscholingsbehoefte doorgaans niet erg hoog. De gewenste aandacht, het toegekende belang en de gevoelde bijscholingsbehoefte ten aanzien van deze kennisgebieden variëren echter naargelang de afstudeerrichting die men gevolgd heeft:

- oud-studenten Verkeersbouwkunde \& verkeerskunde vinden in meerderheid dat infrastructuur/planologie en verkeersbouwkunde belangrijk zijn voor de beroepsuitoefening, en wensen dat in de opleiding aan beide kennisgebieden meer aandacht wordt besteed. Bovendien heeft meer dan een kwart van deze groep afgestudeerden behoefte aan bijscholing op het gebied van verkeersbouwkunde;

- de meeste oud-studenten Gezondheidstechniek \& waterbeheersing vinden waterbouwkundige constructies, vloeistofmechanica en hydrologie/waterbeheersing belangrijk voor de beroepsuitoefening, en wensen meer aandacht in de opleiding voor de twee laatstgenoemde kennisgebieden. Meer dan een kwart van deze oud-studenten heeft behoefte aan bijscholing op het gebied van hydrologie/waterbeheersing;

- oud-studenten Offshoretechnologie vinden in meerderheid dat algemene waterbouwkunde, offshoretechnologie, vloeistofmechanica, waterbouwkundige constructies en staalconstructies belangrijke kennisgebieden zijn voor de beroepsuitoefening; zij wensen dat in de opleiding meer aandacht wordt besteed aan offshoretechnologie en staalconstructies;

- de meeste oud-studenten Utiliteitsbouw vinden dat staalconstructies en betonconstructies belangrijk zijn voor de beroepsuitoefening, en wensen dat het laatstgenoemde kennisgebied meer aandacht krijgt in de opleiding;

- de meerderheid van de oud-studenten Waterbouwkunde acht algemene waterbouwkunde, waterbouwkundige constructies en vloeistofmechanica belangrijk voor de beroepsuitoefening, en wenst meer aandacht in de opleiding voor algemene waterbouwkunde, waterbouwkundige constructies, hydrologie/waterbeheersing en offshoretechnologie. Bovendien heeft meer dan een kwart behoefte aan bijscholing op het gebied van vloeistofmechanica;

- de meeste oud-studenten Mechanica \& constructies vinden dat betonconstructies en staalconstructies belangrijk zijn voor de beroepsuitoefening, en zouden in de opleiding meer aandacht besteed willen zien aan de kennisgebieden betonconstructies en waterbouwkundige constructies. Bovendien heeft meer dan een kwart van deze groep afgestudeerden behoefte aan bijscholing op het gebied van betonconstructies en staalconstructies.

\section{Vaardigheden}

Meer dan $90 \%$ van de respondenten is van mening dat de volgende vaardigheden van belang zijn voor een goede beroepsuitoefening:

- aanpassings- en improvisatievermogen;

- zelfstandigheid, initiatief;

- samenwerken, teamwork;

- plannen, coördineren, organiseren;

- trouble shooting.

Ook voor de overige vaardigheden zijn hoge percentages waar te nemen. Commerciële vaardigheden scoren met $49 \%$ het laagst. 
$-40-$

Het grote belang dat civiel-ingenieurs toekennen aan vaardigheden wordt weerspiegeld in de bevinding dat alle vaardigheden meer aandacht zouden moeten krijgen tijdens de studie. Uitschieters naar boven zijn de vaardigheden met betrekking tot:

- leiding geven;

- kennis overdragen;

- plannen, coördineren en organiseren;

- contacten leggen en onderhouden met cliënten, opdrachtgevers e.d.

Gezien het grote belang van vaardigheden in combinatie met de bevinding dat hieraan tijdens de studie meer aandacht zou moeten worden besteed, is het niet verwonderlijk dat de behoefte aan bijscholing in vaardigheden aanzienlijk is. Voor de volgende vaardigheden heeft meer dan een derde van de respondenten behoefte aan bijscholing (gehad):

- leiding geven;

- contacten leggen en onderhouden met cliënten, opdrachtgevers e.d.;

- commerciële kennis en vaardigheden;

- kennis overdragen.

Vanuit de beroepen gezien heeft meer dan de helft van de managers behoefte aan bijscholing op de vaardigheden commerciële kennis, voorlichten, contacten leggen en leiding geven. 


\section{SAMENVATTING}

Ten behoeve van de visitatiecommissie 'Civiele Techniek, Bouwkunde en Geodesie' heeft de Faculteit der Civiele Techniek door het ROA een onderzoek laten verrichten naar de aansluiting opleiding-werk en de arbeidsmarktpositie van haar afgestudeerden. In dit onderzoek heeft het Bureau Onderwijs en Onderzoek van de Faculteit der Civiele Techniek gezorgd voor de mailing en de administratie van de enquête. De respons onder de aangeschreven oud-studenten bedroeg $54 \%$. De geënquêteerde populatie komt wat de verdeling naar afstudeerjaar en naar afstudeerrichting betreft goed overeen met de totale populatie.

\section{Achtergrondkenmerken}

De onderzochte populatie van civiel-ingenieurs kan als volgt worden getypeerd:

- geslacht: mannelijk (95\%);

- vooropleiding: VWO (86\%);

- oordeel over de aansluiting van de vooropleiding en de propedeuse Civiele Techniek: positief (97\%);

- gemiddelde studieduur: 5.9 jaar (met een HTS-vooropleiding: 5.1 jaar);

- gemiddelde leeftijd bij afstuderen: 25.4 jaar.

\section{Oordeel over de opleiding}

Met de invoering van de tweefasenstructuur is de duur van de opleiding teruggebracht naar vier jaar. Het eindniveau na de vierjarige cursusduur is voor de opleiding Civiele Techniek volgens $48 \%$ van de bevraagde oud-studenten te laag. Daar staat tegenover dat $52 \%$ het eindniveau precies goed vindt. De meerderheid $(83 \%)$ vindt ook dat de opleiding over het geheel genomen redelijk te doen is.

Het aantal af te leggen tentamens, de gerichtheid van de opleiding op inzicht versus feitenkennis, de omvang en inhoud van het projectonderwijs, de specialisatie van de afstudeerrichtingen en de begeleiding bij het afstudeerproject worden overwegend positief beoordeeld. De meerderheid van de bevraagde oud-studenten:

- vindt het aantal af te leggen tentamens evenwichtig (76\%);

- oordeelt dat de gerichtheid van de opleiding op enerzijds inzicht en anderzijds feitenkennis evenwichtig is $(75 \%)$;

- vindt 10 werkweken voor projectonderwijs voldoende (52\%), waarbij ontwerpen en construeren, onderzoeksvaardigheden en schriftelijk presenteren volgens de meeste oud-studenten voldoende aan bod komen;

- vindt dat de door hen gekozen afstudeerrichting, met uitzondering van de richting Planning, ontwerpen \& organisatie, voldoende gespecialiseerd is (76\%);

- is tevreden over de begeleiding bij het afstudeerproject $(73 \%)$. 
Naar de mening van de meeste oud-studenten zou de opleiding met name op de volgende drie punten verder kunnen worden verbeterd. In de eerste plaats zou in de opleiding een zwaarder accent mogen liggen op de praktische toepassing van theorie. In de tweede plaats zou, volgens oud-studenten, het eindniveau van de opleiding verhoogd kunnen worden (de helft vindt het eindniveau te laag). In de derde plaats zou de faculteit meer afstudeerprojecten in het buitenland kunnen creëren ( $84 \%$ acht dit wenselijk).

In het onderzoek zijn drie indicaties naar voren gekomen voor het belang dat oud-studenten hechten aan de praktische toepassing van theorie:

- de helft van de respondenten (52\%) is van mening is dat in de opleiding te veel nadruk wordt gelegd op theorie en te weinig op de praktische toepassing ervan $147 \%$ vindt de verhouding tussen theorie en praktijk evenwichtig);

- in het projectonderwijs mag volgens de meeste oud-studenten (62\%) best wat meer aandacht worden besteed aan het toepassen van theorie in de praktijk;

- oud-studenten zijn in meerderheid $(65 \%)$ van mening dat een half jaar voor een afstudeerproject te kort is (35\% vindt een half jaar voor dit doel precies genoeg).

\section{Arbeidsmarktintrede}

Civiel-ingenieurs hebben weinig problemen met het vinden van werk: het aandeel van werklozen daalt immers snel, van $17 \%$ in de derde maand na afstuderen tot $7 \%$ in de zesde maand na afstuderen. Eén jaar na afstuderen is nog slechts $3 \%$ van degenen die zich op de arbeidsmarkt aanbieden werkloos. De onderzochte civiel-ingenieurs veranderen vaker van functie $(67 \%)$ dan van werkorganisatie $(42 \%)$. Bijgevolg is $20 \%$ al eens binnen een werkorganisatie van functie veranderd. De meeste civiel-ingenieurs $(87 \%)$ schijnen tevreden te zijn met hun baan; zij zijn althans niet op zoek naar ander werk. Vrouwelijke respondenten hebben doorgaans geen problemen ervaren met de acceptatie als vrouwelijke ingenieur of met de combinatie carrière/ouderschap.

\section{Baankenmerken}

De meeste geënquêteerde civiel-ingenieurs werken in loondienst $(98 \%)$, hebben een vaste aanstelling $(80 \%)$ en oefenen full-time functies uit $(97 \%)$. Contractueel werkt men gemiddeld 39.5 uur per week; feitelijk werkt men gemiddeld 45.6 uur per week. Per saldo werkt men dus gemiddeld 6.1 uur per week over.

Bijna de helft van de betaald werkende respondenten heeft een leidinggevende functie, waarin men doorgaans aan 1-4 medewerkers leiding geeft. Oud-studenten Waterbouwkunde, Utiliteitsbouw, Verkeersbouwkunde \& verkeerskunde en Planning, ontwerpen \& organisatie werken het vaakst als projectleider, oud-studenten Mechanica \& constructies en Offshoretechnologie als constructeur en oud-studenten Gezondheidstechniek \& waterbeheersing als adviseur. Wat de branche betreft, komen oud-studenten Utiliteitsbouw, Mechanica \& constructies, Gezondheidstechniek \& waterbeheersing, Offshoretechnologie en Verkeersbouwkunde \& verkeerskunde het 
vaakst terecht in advies-/ingenieursbureaus. Oud-studenten Planning, ontwerpen \& organisatie zijn het vaakst werkzaam in aannemers-/bouw-/baggerbedrijven. Afgestudeerde waterbouwkundigen werken ongeveer even vaak in advies-/ingenieursbureaus als in aannemers-/bouw/baggerbedrijven. Overigens werkt de grootste groep respondenten $(51 \%)$ in Nederlandse bedrijven.

De meeste civiel-ingenieurs starten hun loopbaan in functies waarvoor een universitaire opleiding is vereist $(81 \%)$, en zetten na verandering van functie hun loopbaan in universitaire functies voort $(87 \%)$. Ook starten de meeste civiel-ingenieurs hun loopbaan in functies waarvoor de studierichting Civiele Techniek specifiek is vereist $(61 \%)$, en zetten na functieverandering hun loopbaan in dergelijke qua opleidingsrichting aansluitende functies voort $(62 \%)$. Functieverandering impliceert in de meeste gevallen de overgang van een functie waarvoor werkervaring niet is vereist naar een functie waarvoor werkervaring wel vereist is.

\section{Aans/uiting opleiding-beroep}

De mogelijke kwalitatieve discrepanties tussen de kwalificaties die in het onderwijs worden bijgebracht en de kwalificaties die worden vereist vanuit het werkveld, zijn onderverdeeld in kennisgebieden (bijvoorbeeld mechanica, hydrologie) en vaardigheden (bijvoorbeeld leiding geven, samenwerken). Gebleken is dat de scores op vaardigheden doorgaans hoger zijn dan de scores op kennisgebieden. Dit wil zeggen dat vaardigheden door de bank genomen belangrijker worden geacht voor de beroepsuitoefening dan kennisgebieden, dat vaardigheden tijdens de opleiding meer aandacht moeten krijgen, terwijl de bestede aandacht aan een aantal kennisgebieden best wat minder kan, en dat de behoefte aan bijscholing in vaardigheden groter is dan de behoefte aan bijscholing in kennisgebieden. Deze bevinding kan uiteraard niet los worden gezien van de verhouding binnen het curriculum tussen onderwijs in kennisgebieden en onderwijs in vaardigheden, en daarmee van de relatieve hoeveelheid vaardigheidsonderwijs dat de oudstudenten tijdens de opleiding hebben meegekregen.

Op basis van de antwoorden op de vragen over de aansluiting tussen opleiding en beroep kunnen de onderscheiden beroepen worden verdeeld in vakinhoudelijke beroepen (constructeurs, adviseurs en specialisten) en de meer organisatorische beroepen (projectleiders en managers). De onderzoekers vormen, wat de aansluiting opleiding-beroep betreft, een aparte groep. Met betrekking tot het belang van de verschillende kennisgebieden en vaardigheden voor een goede beroepsuitoefening is gebleken dat kennisgebieden belangrijker zijn voor vakinhoudelijke beroepen dan voor organisatorische beroepen, terwijl vaardigheden voor managers en projectleiders belangrijker zijn dan voor constructeurs, adviseurs en specialisten.

Bij de vraag of er tijdens de opleiding aan de diverse kennisgebieden en vaardigheden meer, evenveel, of minder aandacht moet worden besteed, komen niet alleen kennisgebieden en vaardigheden naar voren die naar de mening van de respondenten meer aandacht behoeven (bijvoorbeeld civieltechnische informatica, civiele bedrijfskunde, leidinggeven, kennis overdragen, plannen/coördineren/organiseren), maar worden, afhankelijk van de richting waarin men is 
afgestudeerd, ook kennisgebieden genoemd waaraan tijdens de studie minder aandacht zou kunnen worden besteed. De behoefte aan bijscholing is aanzienlijk: van meer dan een kwart van de respondenten bij sommige kennisgebieden, tot meer dan een derde bij sommige vaardigheden. Met name voor de kennisgebieden civiele bedrijfskunde, grondmechanica/geotechniek en civieltechnische informatica en de meeste vaardigheden (met name leiding geven) is de behoefte aan bijscholing groot. 


\section{LITERATUUR}

Dam, J.W. van, J.A.M. Heijke, G.W.M. Ramaekers (1989), Ontwerp van een arbeidsmarktscanner voor academici, ROA-R-1989/3, Maastricht.

Faculteit der Civiele Techniek, TU Delft (1990), Civiel-ingenieur worden in Delft, Faculteit der Civiele Techniek, Delft.

Loo, P.J.E. van de, G.W.M. Ramaekers, R.K.W. van der Velden (1992), HBO-Monitor 1991, HBO-Raad, Den Haag.

Ramaekers G.W.M., J.A.M. Heijke (1991), Arbeidsmarktscanner Rijksuniversiteit Limburg: Afgestudeerden 1986-1989, ROA-R-1991/6, Maastricht.

Velden, R.K.W. van der, E.J.T.A. Willems (1992), The market position of occupations and types of education, Contribution to the symposium Education and the Labour Market: From Research to Information for Policy-Making, ROA, Maastricht.

Vereniging van Samenwerkende Nederlandse Universiteiten (1990), Gids voor de onderwijsvisitatie. Herziene uitgave van de Gids voor Externe Kwaliteitszorg, VSNU, Utrecht. 


\section{BIJLAGE 1. TABELLEN}

Tabel 5.4. Belangrijkste branches, naar afstudeerrichting (in \%)

M\&C:

- Advies-/ingenieursbureau constructie $\quad 25$

- Aannemers-/bouw-/baggerbedrijf 20

- Advies-/ingenieursbureau overig * 17

- Overige onderzoeksinstellingen* ${ }^{*} \quad 9$

WB:

- Aannemers-/bouw-/baggerbedrijf 30

- Rijkswaterstaat, waterleiding, provincie 9

- Advies-/ingenieursbureau water \& milieu 7

- Advies-/ingenieursbureau geotechniek 7

- Advies-/ingenieursbureau constructie 6

- Advies-/ingenieursbureau overig * 9

- Gemeente 7

- Overige onderzoeksinstellingen * $\quad 6$

OT:

- Aannemers-/bouw-/baggerbedrijf 23

- Olie-exploitatie $\quad 23$

- Advies-/ingenieursbureau offshore $\quad 15$

- Advies-/ingenieursbureau constructie $\quad 15$

- Advies-/ingenieursbureau overig " 23

UB:

- Aannemers-/bouw-/baggerbedrijf 29

- Advies-/ingenieursbureau constructie 24

- Advies-/ingenieursbureau projectmanagement 6

- Advies-/ingenieursbureau overig * 29

- Distributie, transport 6

G\&W:

- Advies-/ingenieursbureau water \& milieu 44

- Advies-/ingenieursbureau overig * 7

- Rijkswaterstaat, waterleiding, provincie 9

- Universiteit 7

- Overige onderzoeksinstellingen "

VK:

- Universiteit 17

- Aannemers-/bouw-/baggerbedrijf 13

- Advies-/ingenieursbureau verkeer 13

- Advies-/ingenieursbureau overig * 17

- Rijkswaterstaat, waterleiding, provincie 8

- Rijk 8

- Overige overheid; incl. onderwijs 8

POO:

- Aannemers-/bouw-/baggerbedrijf $\quad 44$

- Advies-/ingenieursbureau projectmanagement 9

- Advies-/ingenieursbureau constructie 5

- Advies-/ingenieursbureau overig * 9

- Gemeente 7

- Universiteit

* geen constructie/geotechniek/offshore/utiliteitsbouw/water \& milieu/verkeer/projectmanagement

* geen universiteit 
Tabel 1. Het aandeel van betaald-werkenden die het desbetreffende kennisgebied/vaardigheid tamelijk of zeer belangrijk vinden voor de beroepsuitoefening, naar beroep (in \%)

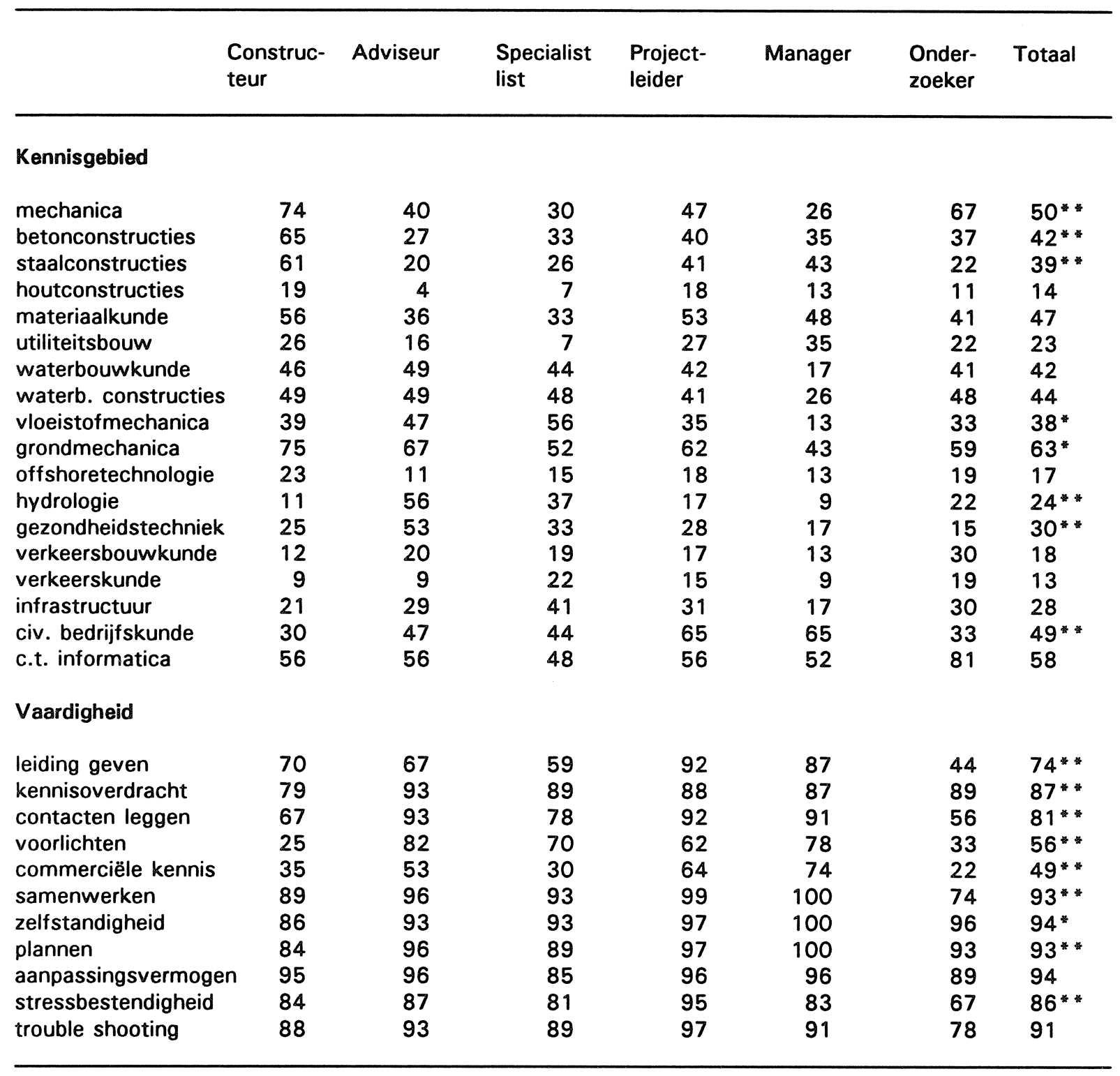

* verschillen significant op $5 \%$ niveau

* verschillen significant op $1 \%$ niveau 
Tabel 2. Aandacht die men in de opleiding aan het desbetreffende kennisgebied/vaardigheid zou willen besteden, naar afstudeerrichting (gemiddelde score en standaardafwijking)

\begin{tabular}{|c|c|c|c|c|c|c|c|c|}
\hline & MC & WB & OT & UB & G\&W & VK & POO & Totaal \\
\hline \multicolumn{9}{|l|}{ Kennisgebied } \\
\hline \multirow[t]{2}{*}{ mechanica } & .16 & .08 & .08 & .06 & -.19 & -.17 & -.02 & $.01 * *$ \\
\hline & .45 & .33 & .28 & .24 & .45 & .49 & .27 & .40 \\
\hline \multirow[t]{2}{*}{ betonconstructies } & .14 & -.06 & .08 & .12 & -.28 & -.17 & -.05 & $-.04 * *$ \\
\hline & .40 & .37 & .28 & .49 & .45 & .39 & .30 & .41 \\
\hline \multirow[t]{2}{*}{ staalconstructies } & .03 & -.04 & .15 & .06 & -.23 & -.13 & .00 & $-.04 *$ \\
\hline & .32 & .28 & .38 & .43 & .43 & .34 & .38 & .37 \\
\hline \multirow[t]{2}{*}{ houtconstructies } & -.03 & -.13 & -.23 & .06 & -.28 & -.13 & .00 & $-.10^{*}$ \\
\hline & .42 & .40 & .44 & .43 & .45 & .34 & .44 & .43 \\
\hline \multirow[t]{2}{*}{ utiliteitsbouw } & .02 & -.16 & -.23 & .06 & -.17 & -.17 & .07 & $-.07 *$ \\
\hline & .44 & .42 & .44 & .43 & .50 & .39 & .51 & .46 \\
\hline \multirow[t]{2}{*}{ waterbouwkunde } & -.02 & .14 & .08 & .00 & -.05 & -.04 & .05 & .02 \\
\hline & .35 & .40 & .28 & .37 & .30 & .47 & .49 & .39 \\
\hline \multirow{2}{*}{ waterb. constructies } & .14 & .18 & .08 & .00 & .02 & -.09 & .10 & .09 \\
\hline & .40 & .39 & .28 & .37 & .41 & .42 & .48 & .41 \\
\hline \multirow[t]{2}{*}{ vloeistofmechanica } & -.05 & .10 & -.08 & -.06 & .21 & -.17 & -.12 & $.00 * *$ \\
\hline & .35 & .41 & .28 & .25 & .47 & .49 & .33 & .40 \\
\hline \multirow[t]{2}{*}{ grondmechanica } & .22 & .38 & .00 & .00 & .16 & .22 & .12 & $.20^{*}$ \\
\hline & .42 & .49 & .00 & .35 & .43 & .67 & .45 & .47 \\
\hline \multirow[t]{2}{*}{ offshoretechnologie } & .03 & .12 & .15 & .00 & -.16 & -.09 & -.07 & -.01 \\
\hline & .49 & .38 & .38 & .35 & .37 & .51 & .46 & .44 \\
\hline \multirow[t]{2}{*}{ hydrologie } & -.07 & .20 & -.23 & -.06 & .21 & -.09 & -.12 & .02 * \\
\hline & .49 & .40 & .44 & .24 & .47 & .42 & .33 & .44 \\
\hline \multirow[t]{2}{*}{ gezondheidstechniek } & -.03 & .12 & -.15 & -.06 & .50 & .17 & .17 & $.13 *$ \\
\hline & .46 & .48 & .55 & .24 & .51 & .65 & .58 & .54 \\
\hline \multirow[t]{2}{*}{ verkeersbouwkunde } & .00 & -.10 & -.23 & -.12 & -.12 & .39 & -.02 & $-.03 *$ \\
\hline & .50 & .42 & .44 & .33 & .39 & .50 & .35 & .45 \\
\hline \multirow[t]{2}{*}{ verkeerskunde } & -.05 & -.08 & -.23 & -.12 & -.12 & .17 & -.10 & -.07 \\
\hline & .47 & .45 & .44 & .33 & .39 & .58 & .43 & .45 \\
\hline infrastructuur & -.19 & -.04 & -.31 & .00 & .05 & .17 & .00 & -.04 \\
\hline & .58 & .54 & .48 & .50 & .43 & .58 & .58 & .55 \\
\hline civ. bedrijfskunde & .24 & .38 & .08 & .24 & .28 & .26 & .67 & $.34 *$ \\
\hline & .57 & .53 & .64 & .56 & .55 & .45 & .48 & .56 \\
\hline c.t. informatica & .32 & .36 & .08 & .18 & .40 & .43 & .48 & .36 \\
\hline & .54 & .49 & .64 & .39 & .58 & .66 & .55 & .55 \\
\hline Vaardigheid & & & & & & & & \\
\hline leiding geven & .44 & .63 & .46 & .56 & .52 & .57 & .60 & .54 \\
\hline & .60 & .49 & .66 & .51 & .51 & .59 & .54 & .55 \\
\hline kennisoverdracht & .39 & .45 & .46 & .63 & .60 & .39 & .60 & .49 \\
\hline & .59 & .50 & .52 & .62 & .50 & .66 & .59 & .56 \\
\hline contacten leggen & .37 & .33 & .46 & .38 & .48 & .57 & .60 & .44 \\
\hline & .55 & .48 & .52 & .62 & .51 & .59 & .54 & .54 \\
\hline voorlichten & .14 & .18 & .08 & .50 & .33 & .39 & .45 & $.28 * *$ \\
\hline & .51 & .39 & .49 & .52 & .48 & .58 & .55 & .51 \\
\hline commerciële Kennis & .31 & .29 & .31 & .50 & .34 & .43 & .48 & .36 \\
\hline & .56 & .50 & .48 & .52 & .48 & .59 & .55 & .53 \\
\hline samenwerken & .20 & .31 & .38 & .50 & .33 & .26 & .38 & .31 \\
\hline & .48 & .47 & .51 & .63 & .48 & .54 & .54 & .51 \\
\hline zelfstandigheid & .27 & .43 & .31 & .38 & .45 & .26 & .50 & .38 \\
\hline & .52 & .50 & .48 & .62 & .50 & .62 & .55 & .53 \\
\hline plannen & .34 & .47 & .54 & .56 & .64 & .39 & .50 & .48 \\
\hline & .51 & .50 & .52 & .63 & .48 & .58 & .55 & .53 \\
\hline aanpassingsvermogen & .26 & .26 & .23 & .50 & .32 & .39 & .31 & .30 \\
\hline & .44 & .49 & .44 & .52 & .47 & .66 & .52 & .50 \\
\hline stressbestendigheid & .29 & .22 & .31 & .44 & .26 & .48 & .43 & .32 \\
\hline & .50 & .46 & .48 & .63 & .45 & .67 & .55 & .52 \\
\hline trouble shooting & .31 & .26 & .46 & .63 & .50 & .48 & .46 & .40 \\
\hline & .50 & .49 & .52 & .50 & .51 & .67 & .55 & .53 \\
\hline
\end{tabular}

* verschillen significant op $5 \%$ niveau

* verschillen significant op $1 \%$ niveau

ROA-onderzoek afgestudeerden Civiele Techniek Delft, mei 1993. 
Tabel 3. Het aandeel van betaald werkenden die behoefte hebben aan bijscholing op het desbetreffende kennisgebied/vaardigheid, naar afstudeerrichting (in \%)

\begin{tabular}{|c|c|c|c|c|c|c|c|c|c|}
\hline & MC & WB & OT & UB & G\&W & VK & POO & Totaal & \\
\hline \multicolumn{10}{|l|}{ Kennisgebied } \\
\hline mechanica & 27 & 15 & 8 & 12 & 2 & 8 & 12 & 14 & $*$ \\
\hline betonconstructies & 27 & 15 & 8 & 18 & 4 & 8 & 19 & 16 & \\
\hline staalconstructies & 25 & 17 & 8 & 6 & 2 & 8 & 14 & 14 & \\
\hline houtconstructies & 15 & 11 & 8 & 6 & 2 & 8 & 14 & 10 & \\
\hline utiliteitsbouw & 12 & 11 & 8 & 24 & 2 & 8 & 14 & 11 & \\
\hline waterbouwkunde & 19 & 13 & 15 & 6 & 4 & 8 & 14 & 12 & \\
\hline waterb. constructies & 19 & 22 & 15 & 6 & 7 & 8 & 14 & 14 & \\
\hline vloeistofmechanica & 17 & 30 & 15 & 0 & 13 & 8 & 14 & 16 & \\
\hline grondmechanica & 34 & 37 & 15 & 18 & 18 & 25 & 26 & 27 & \\
\hline offshoretechnologie & 20 & 24 & 15 & 0 & 2 & 8 & 9 & 13 & * \\
\hline hydrologie & 15 & 19 & 8 & 0 & 31 & 8 & 12 & 16 & * \\
\hline gezondheidstechniek & 10 & 19 & 8 & 0 & 38 & 25 & 19 & 19 & * * \\
\hline verkeersbouwkunde & 14 & 13 & 8 & 0 & 4 & 29 & 9 & 11 & \\
\hline verkeerskunde & 12 & 15 & 8 & 0 & 4 & 21 & 14 & 11 & \\
\hline infrastructuur & 15 & 19 & 8 & 12 & 9 & 13 & 14 & 14 & \\
\hline civ. bedrijfskunde & 24 & 22 & 23 & 41 & 27 & 25 & 35 & 27 & \\
\hline c.t. informatica & 17 & 28 & 15 & 18 & 18 & 29 & 40 & 24 & * \\
\hline \multicolumn{10}{|l|}{ Vaardigheid } \\
\hline leiding geven & 42 & 37 & 38 & 53 & 44 & 25 & 51 & 42 & \\
\hline kennisoverdracht & 32 & 37 & 15 & 47 & 27 & 21 & 42 & 33 & \\
\hline contacten leggen & 37 & 30 & 15 & 35 & 33 & 33 & 40 & 33 & \\
\hline voorlichten & 25 & 22 & 15 & 29 & 31 & 29 & 42 & 28 & \\
\hline commerciële kennis & 39 & 24 & 38 & 47 & 27 & 33 & 37 & 33 & \\
\hline samenwerken & 15 & 28 & 15 & 24 & 7 & 17 & 33 & 20 & \\
\hline zelfstandigheid & 25 & 26 & 15 & 24 & 11 & 17 & 35 & 23 & \\
\hline plannen & 31 & 35 & 46 & 35 & 29 & 17 & 30 & 31 & \\
\hline aanpassingsvermogen & 15 & 17 & 8 & 29 & 7 & 17 & 28 & 17 & \\
\hline stressbestendigheid & 25 & 20 & 15 & 35 & 16 & 21 & 33 & 23 & \\
\hline trouble shooting & 25 & 22 & 15 & 35 & 22 & 21 & 35 & 25 & \\
\hline
\end{tabular}

* verschillen significant op $5 \%$ niveau

* verschillen significant op $1 \%$ niveau 
1992

\title{
AANSLUITING OPLEIDING-WERK EN ARBEIDSMARKTPOSITIE VAN DELFTSE CIVIEL-INGENIEURS
}

\author{
VRAGENLIJST
}

Administratieve gegevens

Naam + voorletters:

gehuwde vrouwen worden verzocht hun eigen naam ('meisjesnaam') te vermelden

Straat + huisnummer

Postcode

Woonplaats

Land

Toelichting:

$\mathrm{Na}$ terugzending van het vragenformulier worden bovenstaande administratieve gegevens door het Bureau Onderwijs en Onderzoek (O\&O) van de faculteit Civiele Techniek eerst verwerkt in het adressenbestand van oud-studenten en in het responsbestand. Vervolgens wordt het vragenformulier zónder dit voorblad naar het Researchcentrum voor Onderwijs en Arbeidsmarkt (ROA) doorgestuurd voor verwerking en analyse. Het ROA weet dus niet wie het vragenformulier heeft ingevuld. Dit is allén bij het Bureau O\&O bekend. 


\section{Instructies voor het invullenl}

- $U$ wordt verzocht om het codenummer te omcirketen van het antwoord dat voor $u$ van toepassing is.

- Er is steeds maar én antwoord mogelijk (tenzij anders is aangegeven).

- Invulfouten kunt u corrigeren met een kruis door het foutief ingevulde codenummer en een cirkel om het juiste codenummer.

- Antwoorden op 'open vragen' kunt $u$ op de aangegeven stippellijntjes noteren.

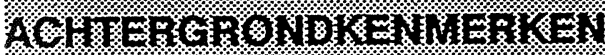

1. Geboortejaar en geslacht.

2. Wanneer bent $u$ met de opleiding Civiele Techniek gestart en wanneer heeft $u$ het doctoraal-diploma behaald?

3. In welke richting(en) binnen Civiele Techniek bent $u$ afgestudeerd? (meer antwoorden mogelijk) geboortejaar: $\quad 19 . \ldots . . \quad \mathrm{M} / \mathrm{V}$

gestart in: $\quad 19 . . . .$.

doctoraal-diploma behaald in: $19 . . . .$.

1 mechanica \& constructies

2 waterbouwkunde

3 offshore technologie

4 utiliteitsbourw

5 gezondheidstechniek \& waterbeheersing

6 verkeer

7 planning, ontwerpen \& organisatie

8 anders (bijv. vrij doctoraal)
4. Welke vooropleiding gaf $u$ toegang tot de studie Civiele Techniek?
1 HTS

2 WWO

3 andere vooropleiding

5. Hoe was de aansluiting tussen uw vooropleiding

4 slecht

\section{(O) ORBEEY OUEA BE OPLEIBING}

6. Ik vond de opleiding Civiele Techniek over het geheel genomen:

7. Het eindniveau na de vierjarige cursusduur is voor de opleiding Civiele Techniek:

8. In het derde studiejaar moeten ongeveer 20 tentamens worden afgelegd, on in de eerste helft van de vierde jaar ongeveer 10.

9. a. De gerichtheid van de opleiding Civiele Techniek op inzicht en feitenkennis was:
1 moeilijk

redelijk to doen

gemakkelijk

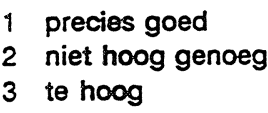

3 te hoog

Ik vind het aantal tentamens:

1 precies goed

2 te groot

3 to klein
1 in evenwicht

2 te veel nadruk op inzicht (en basiskennis)

3 te veel nadruk op feitenkennis 
b. De verhouding in de opleiding Civiele Techniek tussen theorie on de toepassing ervan was:

10. De door mij gekozen afstudeerrichting binnen Civiele Techniek was:

11. a. Zou u veel veranderen als u (de opbouw van) het studieprogramma mocht herindelen?

nee

2 ja
1 in evenwicht

2 to veel nadruk op theorie

3 to veel nadruk op toepassing

1 voldoende gespecialiseerd

2 te algemeen

3 te specialistisch

b. Zo ja, wat zou u vooral willen veranderen?

12. Van welke activiteiten van de studievereniging

'Practische Studie' heeft u tijdens uw opleiding

1 van geen enkele activiteit

Civiele Techniek veel profijt gehad?

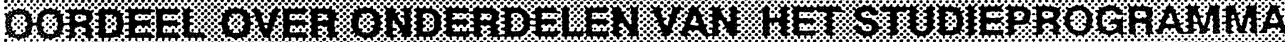

\section{A. Basisstudie}

13. In de eerste tweo studiejaren (basisstudie) zijn de studiepunten als volgt over vijf hoofdgroepen verdeeld:

$\begin{array}{lr}\text { wiskunde } & 21 \% \\ \text { mechanica } & 27 \% \\ \text { constructieleerlmateriaalkunde } & 23 \% \\ \text { algemene Civiele Techniek } & 15 \% \\ \text { informaticalcomputertoepassingen } & 6 \% \\ \text { projectonderwijs } & 8 \% \\ & \end{array}$

totaal

$100 \%$
Zou ú de studiepunten anders verdelen?

$\begin{array}{ll}1 \text { nee } & \\ 2 \mathrm{ja} & \\ & \\ \text { Indien ja, hoe dan? } & \\ & \\ \text { wiskunde } & \ldots . . \% \\ \text { mechanica } & \ldots . \% \\ \text { constructieleer/materiaalkunde } & \ldots . \% \\ \text { algemene Civiele Techniek } & \ldots . \% \\ \text { informatica/computertoepassingen } & \ldots . . \% \\ \text { projectonderwijs } & \ldots . \% \\ \text { totaal } & 100 \%\end{array}$

\section{B. Projectonderwijs}

14. a. In de eerste drie studiejaren worden in totaal 10 'werkweken' besteed aan projectonderwijs.
Ik vind dit:

1 voldoende

2 te weinig

3 te veel

b. Eventuele toelichting 
15. Hieronder wordt een aantal aspecten genoemd die in het projectonderwijs aan bod komen. Moet tijdens het projectonderwijs aan het genoemde aspect meer, evenveel of minder aandacht worden besteed? (In vergelijking met de hoeveelheid aandacht die het aspect tijdens úw opleiding heeft gehad).

$\begin{array}{lll}\begin{array}{l}\text { meer } \\ \text { aandacht }\end{array} & \begin{array}{l}\text { evenveel } \\ \text { aandacht }\end{array} & \begin{array}{l}\text { minder } \\ \text { aandacht }\end{array}\end{array}$

Ontwerpen en construeren

Toepassen van theorie in praktijk

Onderzoeksvaardigheden

Schriftelijk presenteren (brieven, verslagen, rapporten)

Mondeling presenteren (vergaderen, onderhandelen, presentatie voor publiek)

$\begin{array}{lll}1 & 2 & 3 \\ 1 & 2 & 3 \\ 1 & 2 & 3 \\ 1 & 2 & 3 \\ 1 & 2 & 3\end{array}$

\section{Afstudeerproject}

16. Waar heeft u uw afstudeerproject verricht?

17. Voor een afstudeerproject is een half jaar beschikbaar. Ik vind een half jaar voor dit doel:

18. a. Hoe vond $u$ de begeleiding tijdens het afstudeerproject?

b. Indien matig of slecht, waarin schoot de begeleiding dan tekort?
1 binnen (een onderzoeksproject van) de faculteit CT

2 buiten de faculteit CT

1 te kort

2 precies genoeg

3 te lang

1 goed

2 redelijk

3 matig

4 slecht
19. a. Indien geschikte afstudeerprojecten in het buitenland beschikbaar waren geweest, had u daarvan dan gebruik gemaakt?

b. Vindt $u$ het wenselijk dat de faculteit $C T$ afstudeerprojecten in het buitenland creëert?
1 nee

2 ja

3 niet van toepassing (ik heb mijn afstudeerproject in het buitenland gedaan)

1 nee

2 ja

\section{SITUATIE NA AFSTUDEREN}

20.

Bent u na de opleiding Civiele Techniek een vervolgopleiding gaan volgen?
1 nee

2 ja, ben gaan werken aan promotie bij de faculteit CT

3 ja, ben inmiddels gepromoveerd bij de faculteit CT

4 ja, een andere vervolgopleiding, $\mathrm{nl}$.: 
21. Geef in de onderstaande kalender voor iedere maand aan wat het beste paste bij uw situatie in de desbetreffende maand. Het gaat om de eerste 12 maanden na afstuderen én om de maand voorafgaand aan het invullen van deze vragenlijst. $U$ mag per maand maar één codenummer invullen. Maak gebruik van de volgende codenummers:

1 = betaald werk (incl. in combinatie met opleiding), voor minimaal 12 uur per week

2 = student

$3=$ werkzoekend, terwijl geen of minder dan 12 uur per week betaald werk wordt verricht

4 = militaire dienstplicht

5 = vervangende dienstplicht

6 = huisvrouw/huisman

7 = geheel of gedeeltelijk arbeidsongeschikt

8 = vrijwilligerswerk of onbetaald werk met behoud van uitkering

9 = anders, $\mathrm{nl}$.:

\begin{tabular}{|l|l|l|l|l|l|l|l|l|l|l|l|l|l|l||}
\hline Maand & 1 & 2 & 3 & 4 & 5 & 6 & 7 & 8 & 9 & 10 & 11 & 12 & \\
\hline Uw situatie & & & & & & & & & & & & & \\
\hline
\end{tabular}

22. Heeft u na de opleiding Civiele Techniek een betaalde baan van minimaal 12 uur per week gehad? Imilitaire of vervangende dienstplicht wordt niet als betaald werk gerekend)

23. a. Bij hoeveel organisaties heeft $u$ na het afstuderen gewerkt? (Incl. de eventuele huidige werkgever of een eventueel eigen bedrijf). Uitzendperiodes ieder afzonderlijk meetellen. Laat dienstplicht buiten beschouwing.

b. In hoeveel verschillende functies heeft u na in: functies het afstuderen gewerkt? (incl. de eventuele huidige functie). Tel functiewijziging door bijv. promotie of aanzienlijke verandering van de inhoud van uw werkzaamheden óók mee.

Laat ook hier dienstplicht buiten beschouwing.

\section{EERSTE EN HUDIGE BAAN}

In dit vragenblok worden steeds twee functies beschouwd: de eerste betaalde functie na het afstuderen en de betaalde functie die $u$ op dit moment heeft, c.q. de laatst uitgeoefende functie wanneer $u$ op dit moment niet langer werkzaam bent.

Wanneer $u$ nog steeds in de eerste functie werkzaam bent, of slechts één functie heeft gehad, hoeft $u$ de kolom 'huidige functie' niet in te vullen.

$\begin{array}{ll}\text { Eerste functie } & \text { Huidige/laatste } \\ \text { na afstuderen } & \text { functie }\end{array}$

24. Welk opleidingsniveau werd voor uw functie minimaal door uw werkgever vereist?

VWO-, MBO-niveau of lager

HBO-niveau

voortgezet $\mathrm{HBO}$ - of $1 \mathrm{e}$ fase WO-niveau

$2 e$ fase WO-niveau

$\begin{array}{lll}1 & \text { nee } & \text { ga door met vraag } 37 \\ 2 & \text { ja } & \text { ga door met vraag } 23\end{array}$

bij: ..... organisaties

25. Welke opleidingsrichting werd voor uw functie vereist?

- geen specifieke opleidingsrichting

een geheel andere dan Civiele Techniek

- Civiele Techniek of een verwante opleidingsrichting

- uitsluitend Civiele Techniek, echter zonder aanduiding van de afstudeerrichting

- mijn specifieke afstudeerrichting binnen Civiele Techniek

- een andere afstudeerrichting binnen Civiele Techniek dan de eigen functie 
26. Werd voor uw functie werkervaring vereist?

nee

ja
1

1

\section{Voor vrouwelijke ingenieurs:}

27. a. Heeft u bij de functie-uitoefening problemen ervaren met de acceptatie als vrouwelijke ingenieur?

ja

b. Zo ja, welk was/is voor u het grootste probleem?

in eerste functie

in huidige/laatste functie

28. a. Heeft u bij de functie-uitoefening problemen ervaren met de combinatie carrière/ouderschap?

nee

b. Zo ja, welk was/is voor u het grootste probleem?

in eerste functie

in huidige/laatste functie

29. Heeft $u$ belangstelling voor (informeel) overleg tussen vrouwelijke civiel-ingenieurs?

1 nee

2 ja

\section{HUDBIE WERKMRING}

Dit vragenblok heeft betrekking op het betaald werk dat u momenteel verricht c.q. uw laatst uitgeoefend betaald werk indien u op dit moment geen betaald werk meer verricht.

Indien $\mathrm{u}$ tegelijkertijd meer dan én baan heeft (gehad), hebben de vragen $30 \mathrm{t} / \mathrm{m} 36$ allén betrekking op de baan met de meeste arbeidsuren!

30. a. Wat is de benaming voor uw beroep/functie?

b. Omschrijf uw voornaamste werkzaamheden. (leraren worden verzocht ook het vak aan te geven dat zij doceren).

31. a. In welk dienstverband bent $u$ werkzaam?
1 in loondienst (incl. werk via uitzendbureau) ga verder met vraag 31b.

2 werkzaam met nul-uren contract of als oproepkracht

3 als zelfstandige voor eigen rekening of risico (eigen bedrijf of praktijk)

4 free-lance

5 anderszins ga verder met vraag 316 .

ga verder met vraag 32 ga verder met vraag 32 ga verder met vraag $31 b$. 
b. Wat voor soort aanstelling heeft $u$ ?

32. Hoeveel uren per week werkt $u$ in uw huidige functie, zowel contractueel als feitelijk?

Ga uit van de laatste maand.

Laat de uren voor nevenfuncties buiten beschouwing.

33. Geeft u leiding aan medewerkers? Zo ja, aan hoeveel?
1 tijdelijke aanstelling via uitzendbureau

tijdelijke aanstelling bij werkgever, voor maximaal 1 jaar

tijdelijke aanstelling bij werkgever, voor langer dan 1 jaar

4 vaste aanstelling (voor onbepaalde tijd)

34. a. Wat is uw totale bruto maandinkomen in uw functie? Excl. vakantiegeld of inkomen voor nevenfuncties. Ga uit van de laatste maand. Reken een eventuele $13 \mathrm{e}$ maand of jaargratificatie voor $1 / 12$ deel mee.

b. Welk deel hiervan bestaat uit eventuele toeslagen voor overwerk, onregelmatig werk, ploegendienst e.d.? IVul ' $O$ ' in wanneer $u$ dergelijke toeslagen niet ontvangt).

35. a. In wat voor een soort organisatie of praktijk bent $u$ (de meeste arbeidsuren) werkzaam? Geef tevens aan welk produkt of dienst er wordt geleverd.

b. Uw werkorganisatie is:

\author{
contractueel : ....... arbeidsuren per week \\ feitelijk \\ arbeidsuren per week
}

geen leiding aan medewerkers

2 leiding aan 1 - 4 medewerkers

3 leiding aan 5 - 9 medewerkers

4 leiding aan 10 - 19 medewerkers

5 leiding aan 20 of meer medewerkers

totale inkomen : ca. $f$ bruto per maand

toeslagen : ca. $f$ bruto per maand soort organisatie/praktijk (bijv. ingenieursbureau) produkt/dienst (bijv. milieu-adviezen)

1 een onderzoeksinstelling (bijv. TNO, WL)

2 de Nederlandse overheid

3 een Nederlands bedrijf

4 een internationaal bedrijf met hoofdzetel in Nederland

5 een buitenlands bedrijf

6 anders, $\mathrm{nl}$.: 
36. Hieronder wordt een aantal aspecten (kennisgebieden en vaardigheden) genoemd die voor een goede beroepsuitoefening van uw huidige functie van belang kunnen zijn. Het is de bedoeling dat $u$ in onderstaand schema voor ieder aspect de drie hieronder gestelde vragen beantwoordt door het juiste cijfer te omcirkelen.

\section{a. Belang}

In hoeverre is het genoemde aspect van belang voor een goede beroepsuitoefening van uw huidige functie?

$$
\begin{aligned}
& 1=\text { zeer belangrijk } \\
& 2=\text { tamelijk belangrijk } \\
& 3=\text { vrij onbelangrijk } \\
& 4=\text { onbelangrijk }
\end{aligned}
$$

\section{b. Aandacht}

Moet tijdens de opleiding Civiele Techniek aan het genoemde aspect meer, evenveel of minder aandacht worden besteed? lin vergelijking met de hoeveelheid aandacht die het aspect tijdens uw opleiding heeft gehad).

\section{c. Bijscholing}

Heeft u behoefte (gehad) aan bijscholing met betrekking tot het genoemde aspect?

$$
\begin{aligned}
& 1=\text { meer aandacht } \\
& 2=\text { evenveel aandacht } \\
& 3=\text { minder aandacht }
\end{aligned}
$$

1. Kennisgebieden:

algemene en toegepaste mechanica

betonconstructies

staalconstructies

houtconstructies

materiaalkunde algemeen

utiliteitsbouw/bouwfysica

algemene waterbouwkunde

waterbouwkundige constructies

vloeistofmechanica

grondmechanica/geotechniek

offshore technologie

hydrologie/waterbeheersing

gezondheidstechniek/milieutechnologie

verkeersbouwkunde

verkeerskunde

infrastructuur/planologie

civiele bedrijfskunde

civiele technische informatica

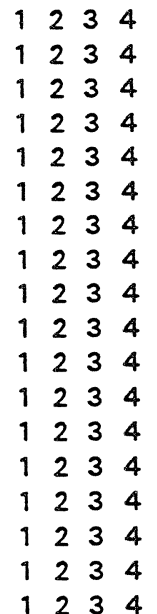

1234

\section{Vaardigheden:}

\section{leiding geven}

kennis overdragen op anderen

contacten leggen en onderhouden met cliënten, opdrachtgevers e.d.

voorlichten, adviseren, verzorgen van public relations

commerciële kennis en vaardigheden (in-/verkoop, marketing, acquisitie)

samenwerken met collega's; werken in teamverband

zelfstandigheid, initiatieven nemen, initiëren van projecten

plannen, coördineren en organiseren van activiteiten

aanpassingsvermogen, flexibiliteit, improvisatievermogen

stressbestendigheid, omgaan met onzekerheid

aanpakken van problemen (trouble shooting)

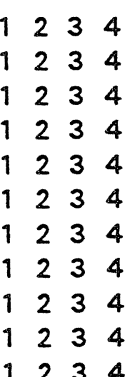

1234

$\begin{array}{lllll}1 & 2 & 3 & 1 & 2 \\ 1 & 2 & 3 & 1 & 2 \\ 1 & 2 & 3 & 1 & 2 \\ 1 & 2 & 3 & 1 & 2 \\ 1 & 2 & 3 & & \\ 1 & 2 & 3 & 1 & 2 \\ 1 & 2 & 3 & 1 & 2 \\ 1 & 2 & 3 & 1 & 2 \\ 1 & 2 & 3 & 1 & 2 \\ 1 & 2 & 3 & 1 & 2 \\ 1 & 2 & 3 & 1 & 2 \\ 1 & 2 & 3 & 1 & 2 \\ 1 & 2 & 3 & 1 & 2 \\ 1 & 2 & 3 & 1 & 2 \\ 1 & 2 & 3 & 1 & 2 \\ 1 & 2 & 3 & 1 & 2 \\ 1 & 2 & 3 & 1 & 2 \\ 1 & & 1 & 2\end{array}$

$123 \quad 12$

$\begin{array}{lllll}1 & 2 & 3 & 1 & 2\end{array}$

$123 \quad 12$

$\begin{array}{lllll}1 & 2 & 3 & 12\end{array}$

$123 \quad 12$

$123 \quad 12$

$123 \quad 12$

$123 \quad 12$

$123 \quad 12$

$123 \quad 12$

123312 


\section{' OP ZOEN WAAR GA NDER WERK}

37. a. Heeft u de afgelopen 4 weken actief naar (ander) werk gezocht?

b. Bent $u$ als werkzoekende bij het arbeidsbureau ingeschreven?

c. Als u nu een (andere) geschikte baan zou vinden, hoe snel kunt u daarmee dan beginnen?
1 nee ga door met vraag 38

2 ja

1 nee

2 ja

1 binnen 2 weken

2 binnen 3 maanden

(i.v.m. opzegtermijn huidige werkkring, afronden vrijwilligerswerk, regelen

kinderopvang, vakantie of ziekte)

3 binnen 3 maanden (maar om een andere reden

dan onder 2 genoemd)

4 na 3 maanden

\section{TOT SLOT}

38. Mocht $u$ eventuele opmerkingen naar aanleiding van deze enquête hebben, dan kunt $u$ deze hiernaast noteren.

Hartelijk dank voor uw medewerking 